Research Article

\title{
Synthesis and Spectral Characterisation of (E)-3-(3-(4 (Dimethylamino)Phenyl) Acrylo-yl)-4-Hydroxy-2H-Chromen-2-One and Their Antibacterial Activity and Acetylcholinesterase Inhibition
}

\author{
Ichraf Slimani $\mathbb{D}^{1},{ }^{1}$ Naceur Hamdi $\mathbb{D}^{1},{ }^{1,2}$ Sadeq M. Al-Hazmy $\mathbb{D}^{\mathrm{D}},{ }^{3,4}$ Ibrahim A. Alhagri $\mathbb{D}^{3,5}$ \\ El-Zeiny M. Ebeid $\left(\mathbb{D},{ }^{6}\right.$ and Ehab A. Okba $\oplus^{6}$ \\ ${ }^{1}$ Research Laboratory of Environmental Sciences and Technologies (LR16ES09), \\ Higher Institute of Environmental Sciences and Technology, University of Carthage, PB 77-P.O. Box 77, 1054 Amilcar, \\ Hammam-Lif, Tunisia \\ ${ }^{2}$ Department of Chemistry, College of Science and Arts at ArRass, Qassim University, P.O. Box 53, ArRass 51921, Saudi Arabia \\ ${ }^{3}$ Department of Chemistry, College of Science, Qassim University, Buraydah, Saudi Arabia \\ ${ }^{4}$ Department of Chemistry, College of Science, Sana'a University, Sana'a, Yemen \\ ${ }^{5}$ Department of Chemistry, Faculty of Science, Ibb University, Ibb, Yemen \\ ${ }^{6}$ Department of Chemistry, Faculty of Science, Tanta University, Tanta, Egypt
}

Correspondence should be addressed to Sadeq M. Al-Hazmy; s.alhzmy@qu.edu.sa

Received 30 August 2021; Revised 5 October 2021; Accepted 28 October 2021; Published 7 December 2021

Academic Editor: Casimiro Mantell

Copyright (C) 2021 Ichraf Slimani et al. This is an open access article distributed under the Creative Commons Attribution License, which permits unrestricted use, distribution, and reproduction in any medium, provided the original work is properly cited.

A new coumarin derivative, (E)-3-(3-(4-(dimethylamino) phenyl) acrylo-yl)-4-hydroxy-2H-chromen-2-one (3), was synthesized by the condensation of 3-acetyl-4-hydroxycoumarin (1) with 4-N,N-dimethylaminobenzaldehyde (2) in the presence of piperidine in ethanol. The structure of the synthesized compound was characterized using spectroscopic data (IR and ${ }^{1} \mathrm{H}$ NMR) and elemental analysis. The antimicrobial properties and acetylcholinesterase inhibition activity (AChEI) of coumarin 3 were investigated, with the highest observed AChEI activity providing $48.25 \%$ inhibition. The electronic absorption and emission spectra revealed that 3 exists as two, main keto-enol tautomers. The ratios of these tautomers in both protic and aprotic solvents with different polarities and dielectric constants were calculated. The fluorescence of coumarin 3 was enhanced upon increasing the medium viscosity, which was due to the resultant molecular rigidity. This criterion was further investigated using DNA, whereby 3 showed enhanced fluorescence upon its uptake in DNA grooves and was therefore tested as a novel DNA fluorescent stain.

\section{Introduction}

Coumarins are an important class of benzopyrones present in various natural products and numerous pharmaceutically valuable compounds [1]. With their privileged scaffold, coumarins exhibit a broad spectrum of biological activity; namely, they act as anticoagulants, antibiotics, and antioxidants, as well as anti-inflammatory, anti-HIV, and anticancer agents. They also exhibit thermal photosensitizing, vasodilator, and estrogenic activities [2,3]. Coumarins are commonly used in the treatment of prostate cancer, renal cell carcinoma, and leukemia and can counteract the side effects of radiotherapy. Both natural and synthetic coumarin derivatives have gained considerable attention because of their photochemotherapy and therapeutic applications for cancer treatment [4].

Novobiocin and clorobiocin are coumarin-derived antibiotics that are used as competitive inhibitors of the bacterial adenosine-5-triphosphate (ATP)-binding gyrase B subunit where the inhibition they provide blocks the negative supercoiling of relaxed DNA [5-7]. Another example is wedelolactone, a natural, coumarin-containing product that 
is used as an antidote for venomous snakebites [8, 9] and as an anticancer agent for breast and prostate carcinomas [10].

Recent research suggests that the connection of a chalcone moiety with the coumarin ring is quite promising for the synthesis of derivatives with enhanced tissue plasminogen activator (TPA) cross-sections [11-13]. During our continuing interest in the synthesis of coumarin derivatives, including 4-hydroxyl coumarin, that demonstrate antibacterial and antioxidant activities [14, 15], we have extended our research to include the synthesis and biological evaluation of new coumarin-chalcone compounds as antibacterial agents and acetylcholinesterase (AChE) inhibitors (AChEIs). Furthermore, since there are few reports describing the synthesis of compounds containing both coumarin and chalcone units [16], this study is greatly important. Coumarin-chalcone derivatives containing a urea moiety are also of interest as they exhibit strong activity against the H4IIE cancer cell line [17].

Chalcones are an important class of aromatic ketones that occur in nature. They consist of an electron donor and an electron acceptor connected by a $\pi$-conjugated spacer. Chalcones can be used in various medical applications due to their antimalarial, anti-infective, anticancer, anti-inflammatory, antifungal, antioxidant, and antituberculosis properties [18]. A unique criterion of chalcones that is associated with their inherent molecular flexibility is their unique, microenvironment-dependent optical properties [19, 20]. For instance, the fluorescence efficiency of these compounds increases substantially in viscous media. Furthermore, nonradiation deactivation via internal conversion is a common phenomenon that occurs in flexible molecules, which leads to such molecules exhibiting weak fluorescence in fluid media [21].

Several coumarin-chalcone hybrid compounds have been synthesized and characterized for their pharmacological properties [22]; their potential to serve as biological [23, 24], antimicrobial [25, 26], anticancer [27], antitrypanosomal, and antioxidant compounds [28]; and their ability to inhibit AChE and butyrylcholinesterase [29]. New coumarin-chalcone hybrids with trypanocidal properties have also been synthesized and characterized [22, 30].

In the present paper, we report the synthesis, characterisation, and bioactivity of a new (E)-3-(3-(4-(dimethylamino) phenyl) acrylo-yl)-4-hydroxy-2H-chromen-2-one (3). The design of our novel coumarin benefits from the bioactivities of both the coumarin and chalcone moieties and simultaneously exploits the ability of the chalcone moiety to serve as a built-in probe for microenvironment probing. These chalcone properties also allowed us to assess the nature of the interaction between our developed coumarin and DNA molecules. The application of this coumarin as a new, potential DNA fluorescent stain is also described herein.

\section{Experimental}

2.1. Synthesis and Characterisation of 3-Acetyl-4-Hydroxy2H-Chromen-2-One. 3-Acetyl-4-hydroxy-2H-chromen-2one was prepared by adding 3-acetyl-4-hydroxycoumarin (1) to a solution of 4-hydroxy- $2 \mathrm{H}$-chromen-2-one ( $\mathrm{g}$, $1.86 \mathrm{mmol})$ in acetic acid $(16 \mathrm{~mL})$ and phosphorus oxychloride $\left(\mathrm{POCl}_{3} ; 5.6 \mathrm{~mL}\right)$. The mixture was heated under reflux for $30 \mathrm{~min}$. After cooling, the precipitate was collected and recrystallized from ethanol to yield 3-acetyl-4-hydroxy$2 \mathrm{H}$-chromen-2-one as white needles. Yield $2.7 \mathrm{~g}$ (90\%); m.p. $135{ }^{\circ} \mathrm{C}$. IR spectrum, $\mathrm{m} \mathrm{cm}^{-1}$ : $3185(\mathrm{OH}) ; 1705$ (CO); 1700 (O-CO lactone). ${ }^{1} \mathrm{H}$ NMR spectrum $\left(\mathrm{CDCl}_{3}\right), \delta$ ppm: 2.72 $\left(3 \mathrm{H}, \mathrm{s}, \mathrm{CH}_{3}\right) ; 7.98(1 \mathrm{H}, \mathrm{s}, \mathrm{H}-5) ; 7.95(1 \mathrm{H}, \mathrm{dd}, 3 \mathrm{~J} 7.8=8.35,4$ $\mathrm{J} 6.8=1.2, \mathrm{H}-8)$; 7.1-7.4 (2H, m, H-6, H-7); 17.69 (1H, s, $\mathrm{OH}) .{ }^{13} \mathrm{C} \mathrm{NMR}$ spectrum $\left(\mathrm{CDCl}_{3}\right), \delta$ ppm: $29.9\left(\mathrm{CH}_{3}\right) ; 178.5$ (CO); 159.8 (C-4); 154.6 (C-2); 101.26 (C-3); 115.0-136.0 (aromatic C). Mass spectrum, $m / z$ (I, \%): 204 [M] (100); 189 (74); 161 (43). Elemental analysis (\%) for $\mathrm{C}_{11} \mathrm{H}_{8} \mathrm{O}_{4}$ : calcd. C, 64.71; H, 3.95; O, 31.34. found C, 64.8; H, 4.1; N, 31.4.

2.2. Synthesis and Characterisation of (E)-3-(3-(4-(Dimethylamino) Phenyl) Acrylo-Yl)-4-Hydroxy-2H-Chromen-2-One (3). A solution of $\mathbf{1}(1 \mathrm{~g}, 5 \mathrm{mmol})$ in ethyl alcohol $(10 \mathrm{~mL})$ and the selected aromatic aldehyde 4 - $N, N$-dimethylaminobenzaldehyde $(2 ; 5 \mathrm{mmol})$ in the presence of piperidine $(1 \mathrm{~mL})$ was refluxed for $10-12 \mathrm{~h}$. The solution was cooled, and water was added to precipitate the desired chalcone compound (3).

2.2.1. 1-(4-Hydroxy-2-Oxo-2H-Chromen-3-Yl)-3-(4-Dimethylaminophenyl)-2-Propen-1-One. Mol. for: $\mathrm{C}_{20} \mathrm{H}_{17} \mathrm{NO}_{4}$, M.wt. 335.35, yield $71 \%$, and m.p. $130-132{ }^{\circ} \mathrm{C}$; IR ( $\mathrm{KBr}$, $\left.\mathrm{cm}^{-1}\right)$ : $3675(\mathrm{OH}), 2987$ (-CH aliphatic stretching), 1726 $(\mathrm{C}=\mathrm{O}), 1698(\mathrm{C}=\mathrm{O})$, and $1541(\mathrm{C}=\mathrm{C}) ;{ }^{1} \mathrm{H} \mathrm{NMR}(400 \mathrm{MHz}$ $\left.\mathrm{CDCl}_{3}, \delta, \mathrm{ppm}\right): 3.06\left(6 \mathrm{H}, \mathrm{s}, \mathrm{H}_{\mathrm{a}, \mathrm{b}}\right), 6.68\left(2 \mathrm{H}, \mathrm{d}, \mathrm{H}_{2^{\prime}, 3^{\prime}}\right)$, 7.28-7.38 (2H, m, $\left.\mathrm{H}_{6,10}\right), 7.62-7.65\left(3 \mathrm{H}, \mathrm{m}, \mathrm{H}_{5^{\prime}, 6^{\prime}, 8^{\prime}}\right)$, and

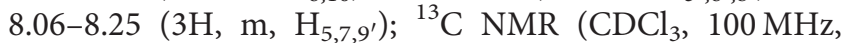
ppm): $40.2\left(\mathrm{C}_{\mathrm{a}, \mathrm{b}}\right), 100.0\left(\mathrm{C}_{3}\right), 111.9\left(\mathrm{C}_{6^{\prime}, 8^{\prime}}\right), 115.8\left(\mathrm{C}_{9}\right), 116.9$ $\left(\mathrm{C}_{10}\right), 117.4 \quad\left(\mathrm{C}_{7}\right), 122.7\left(\mathrm{C}_{6}\right), 124.1\left(\mathrm{C}_{4^{\prime}}\right), 125.8\left(\mathrm{C}_{5}\right)$, 132.3 $\left(\mathrm{C}_{9^{\prime}, 5^{\prime}}\right), 135.4\left(\mathrm{C}_{2^{\prime}}\right), 149.6\left(\mathrm{C}_{3^{\prime}}\right), 153.0\left(\mathrm{C}_{7^{\prime}}\right), 154.6\left(\mathrm{C}_{8}\right)$, $160.7\left(\mathrm{C}_{2}\right), 182.4\left(\mathrm{C}_{4}\right)$, and $190.6\left(\mathrm{C}_{1^{\prime}}\right)$. Elemental analysis (\%) for $\mathrm{C}_{20} \mathrm{H}_{17} \mathrm{NO}_{4}$ : calcd. C, 71.63; $\mathrm{H}, 5.11 ; \mathrm{N}, 4.18$, found $\mathrm{C}$, 71.7; H, 5.2; N, 4.2.

2.3. Electronic Absorption and Emission Spectra. The electronic absorption spectra were recorded on a Cary-400 UVvisible spectrophotometer connected to a Cary data acquisition system using $1-\mathrm{cm}$ matched silica cells. Emission and excitation spectra were recorded using a Jasco FP-8200 spectrofluorometer with an excitation bandwidth of $5 \mathrm{~nm}$, an emission band width of $5 \mathrm{~nm}$, and a Xe lamp light source. Chemicals were purchased from Sigma-Aldrich and used without further purification. All the solvents used in this study were of the highest purity (Merck).

2.4. Theoretical Calculations. Molecular orbital calculations were performed using Gaussian 09 suites [31] and pictured by the Gauss View [32] program. A density functional theory (DFT) employing Becke's three-parameter Lee-Young-Parr functional (B3LYP) and the 6-31G(d) basis set was used to optimize the geometry of the molecular structures of the tautomers of coumarin 3 to a minimum. The dipole moments of the tautomers of $\mathbf{3}$ were also calculated. Electronic 
UV-Vis spectra of 3 in different organic solvents were simulated using time-dependent DFT (TD-DFT) [33] with the $6-31 \mathrm{G}(\mathrm{d})$ basis set.

2.5. Gel Electrophoresis. Gel electrophoresis was performed using a DNA-protein gel electrophoresis unit (model: BioRad Power Pac 300; serial no.: 282BR15744; USA product) with a maximum power of $195 \mathrm{VA}$, a frequency of $-50-60 \mathrm{~Hz}$, and an AC voltage of $-100-120 \mathrm{~V}$. Gel documentation was performed using an illumination system (model: UV Star Biometra 312) with a $312 \mathrm{~nm}$ excitation wavelength.

In a typical run, a Tris/borate/EDTA buffer (denoted TBE buffer, where Tris=(tri-hydroxymethyl) aminomethane and $\mathrm{EDTA}=\mathrm{X}$ ) buffer was prepared in two stages, which are as follows:

(i) A TB solution was first prepared by dissolving $10.8 \mathrm{~g}$ of Tris together with $5.5 \mathrm{~g}$ of boric acid in $900 \mathrm{~mL}$ of distilled water using a magnetic stirrer at room temperature.

(ii) A $4 \mathrm{~mL}$ portion of a $0.5 \mathrm{M}$ EDTA- $\mathrm{Na}_{2}(\mathrm{pH} 8.0)$ solution was added, and the volume was adjusted to $1 \mathrm{~L}$. The resulting buffer was stored at room temperature.

Additionally, an agarose solution containing the fluorescent staining dye was prepared in two steps, which are as follows:

(i) Agarose (1.5 g) was weighed and dissolved in $100 \mathrm{~mL}$ of the TBE buffer solution by heating on a magnetic stirrer until a clear agarose solution was obtained.

(ii) A fluorescent stain $(20 \mu \mathrm{L}$; Midori Green Advance DNA Stain) was added as a gel stain.

\section{Results and Discussion}

3.1. Characterisation. The reaction between 4-hydroxycoumarin and $\mathrm{POCl}_{3}$ in glacial acetic acid under reflux for $24 \mathrm{~h}$ afforded $\mathbf{1}$ in excellent yield (90\%) (Scheme 1) [34].

The IR spectrum of compound 1 revealed a strong band at $3185 \mathrm{~cm}^{-1}$, confirming the presence of an $\mathrm{OH}$ group and a band at $1700 \mathrm{~cm}^{-1}$, which is characteristic of the coumarin $\mathrm{C}=\mathrm{O}$ moiety. The ${ }^{1} \mathrm{H}$ NMR data of $\mathbf{1}$ revealed a signal at $2.72 \mathrm{ppm}$ attributed to the methyl protons, and the aromatic protons resonated between 7.1 and $7.98 \mathrm{ppm}$. The hydroxyl proton $(\mathrm{OH})$ resonated at $17.69 \mathrm{ppm}$.

The synthesis of coumarin-chalcone $\mathbf{3}$ was achieved in one step using a new protocol that involved mixing $\mathbf{1}$ with $\mathbf{2}$ under reflux in the presence of piperidine in ethanol (Scheme 2). The synthesized product was obtained as a solid, and its purity was checked by thin-layer chromatography (eluent: hexane/ethyl acetate, 1/1, v/v).

Conventional chalcone syntheses typically require very long reaction times, ranging from 24 to $36 \mathrm{~h}$ at room temperature [35]. Our protocol incorporates small changes in the reaction conditions, namely, the use of chloroform as the solvent and the incorporation of a mild organic base (e.g., piperidine), which reduces the reaction time to $1-1.5 \mathrm{~h}$. Moreover, the isolation of novel coumarin 3 was facilitated, whose structure was identified using spectroscopic data and elemental analysis.

The IR spectrum of $\mathbf{3}$ showed bands corresponding to $\mathrm{OH}$, (ketone) $\mathrm{C}=\mathrm{O}$, and $\mathrm{C}=\mathrm{C}$ stretching vibrations at $3675 \mathrm{~cm}^{-1}, \quad 1726 \mathrm{~cm}^{-1}$, and $1541 \mathrm{~cm}^{-1}$, respectively (Figure 1). The ${ }^{1} \mathrm{H}$ NMR spectrum of 3 in $\mathrm{CDCl}_{3}$ (Figure 2) showed a singlet at $3.06 \mathrm{ppm}$ for six protons attributed to the methyl groups, a signal at $19.05 \mathrm{ppm}$ for the $\mathrm{OH}$ proton, and multiplets between 7.28 and $8.25 \mathrm{ppm}$ corresponding to the other 10 protons.

The ${ }^{13} \mathrm{C}$ NMR spectrum of 3 in $\mathrm{CDCl}_{3}$ (Figure 3 ) showed a signal at $40.2 \mathrm{ppm}$ corresponding to $\mathrm{C}_{\mathrm{a}, \mathrm{b}}$, whereas that of $\mathrm{C}_{3}$ appeared at $100 \mathrm{ppm}$, that of $\mathrm{C}_{2}$ was noted at $160.7 \mathrm{ppm}$, and that of $\mathrm{C}_{4}$ appeared at $182.4 \mathrm{ppm}$. One downfield signal at $190.6 \mathrm{ppm}$ was attributed to the $\mathrm{C}=\mathrm{O}$ moiety, and the aromatic carbons showed up between 122.7 and $154.6 \mathrm{ppm}$. Coumarin 3 can exist in several tautomeric forms, but the most stable are $\mathbf{A}$ and $\mathbf{B}$, which are stabilized by intramolecular hydrogen bonding (Scheme 3).

\subsection{Biological Activities}

3.2.1. Antibacterial Activity. Coumarin derivatives 1 and $\mathbf{3}$ were screened for their antibacterial effects, as reported in our previous work [36]. The antibacterial activities of compounds 1 and 3 against human pathogenic Grampositive and Gram-negative bacteria were estimated by measuring the zone of inhibition using the disc diffusion method. The synthesized coumarins ( 1 and $\mathbf{3})$ showed activity against all bacteria present in three different concentrations: $0.1,0.3$, and $0.5 \mathrm{mg} / \mathrm{mL}$ (Table 1).

The minimal inhibitory concentrations (MICs) of coumarin derivatives $\mathbf{1}$ and $\mathbf{3}$ were determined against Listeria monocytogenes (ATCC 19117), Salmonella typhimurium (ATCC 14028), and Micrococcus luteus. The activity of ampicillin toward these same microorganism indicators was also tested to compare the activities of the newly synthesized coumarin derivatives with that of a commonly used standard. The results are shown in Table 2.

Coumarin 3 showed better activity $(\mathrm{MIC}=0.314 \mathrm{mg} / \mathrm{mL})$ than that of ampicillin against Micrococcus luteus, but its activity toward Salmonella typhimurium was much lower $(\mathrm{MIC}=0.040 \mathrm{mg} / \mathrm{mL})$. The nature of the $\mathrm{N}, \mathrm{N}$ - dimethylamino group and the presence of hydrogen bonds greatly influence the activity of the compounds with Gram-negative bacteria [37]. The most active compound among the three that were tested was coumarin $\mathbf{3}$, which had the highest activity against the Gram-negative bacterium Salmonella typhimurium (ATCC14028). Notably, this activity of $\mathbf{3}$ is greater than that typically exhibited by the commonly used ampicillin. All three substances exhibited weak effects against the Gram-positive bacteria Listeria monocytogenes (ATCC 19117).

3.2.2. Acetylcholinesterase Inhibition. AChE is the hydrolysis product of the neurotransmitter acetylcholine, which terminates impulse transmission at cholinergic synapses of 


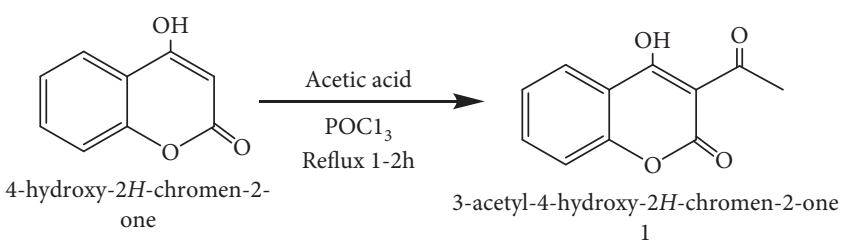

FIGURE 1: Synthesis of 3-acetyl-4-hydroxycoumarine.

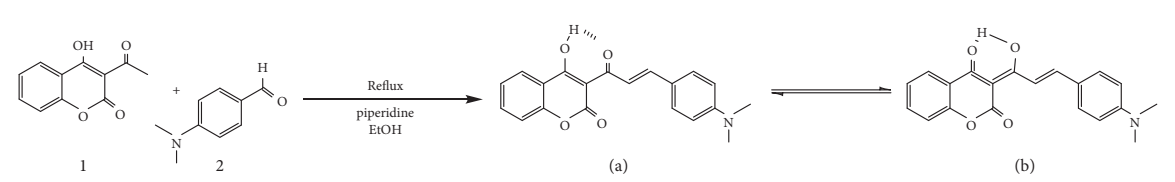

Scheme 2: Synthesis of (E)-3-(3-(4-(dimethylamino) phenyl) acrylo-yl)-4-hydroxy-2H-chromen-2-one (3), which exists as two keto-enol tautomers ( $\mathbf{A}$ and $\mathbf{B})$.

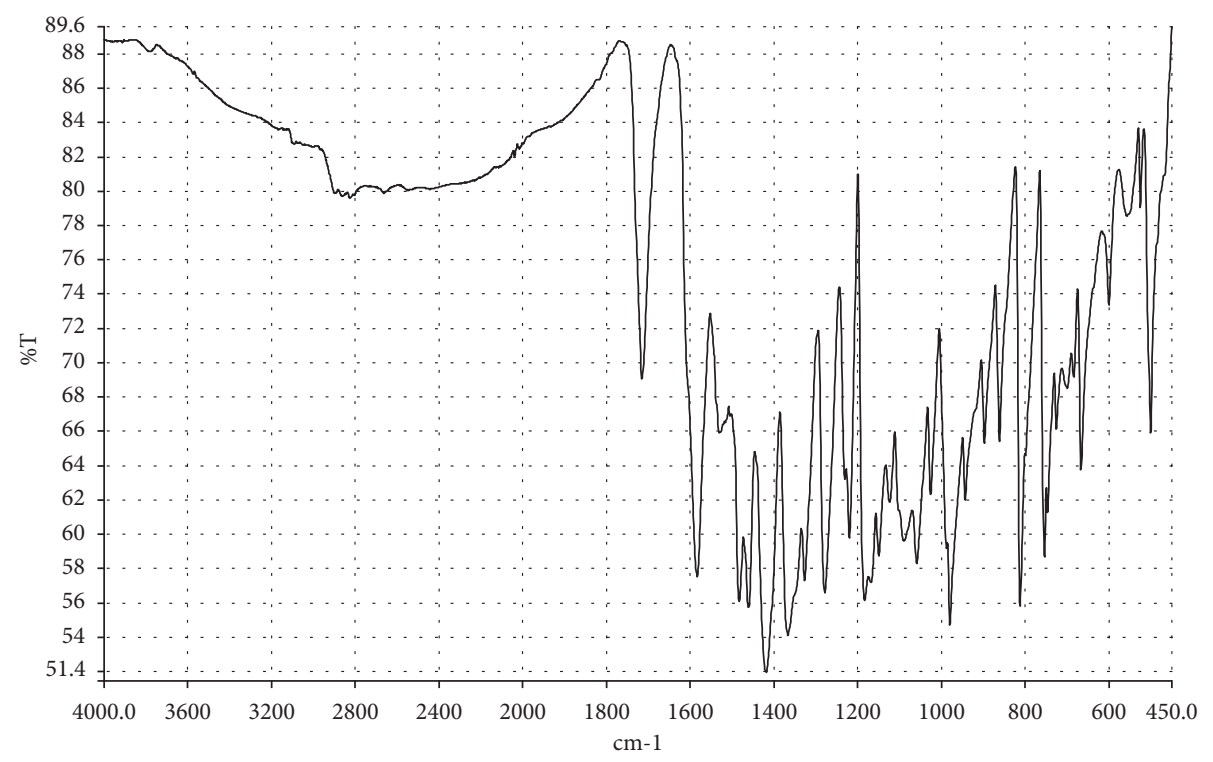

FIGURE 1: FTIR spectrum of coumarin 3.

the central and peripheral nervous systems. Degenerative nervous diseases, such as Alzheimer's disease, have been associated with a deficiency of acetylcholine. AChEIs have been used for the symptomatic treatment of Alzheimer's disorders [38]. The AChE enzyme test was performed as reported previously [39-41], where coumarin 3 showed significant AChEI activity (Table 3 ).

3.3. Absorption and Emission Spectra. The electronic absorption and emission spectra of coumarin $3\left(1 \times 10^{-5} \mathrm{M}\right)$ were measured at room temperature as a function of medium acidity and polarity. The UV-visible absorption spectra of coumarin 3 were collected in 10\% ethanolic-universal buffer solutions of different $\mathrm{pH}$ values. In acidic media $(\mathrm{pH}=2,4$, and 6), a well-developed, broad band was noted at approximately $500 \mathrm{~nm}$, but in basic media ( $\mathrm{pH}=8$ and 10), an absorption band developed at a shorter wavelength of about $400 \mathrm{~nm}$ (Figure 4). The short-wavelength band at approximately $400 \mathrm{~nm}$ is assigned to the keto tautomer, whereas the long-wavelength band at approximately $500 \mathrm{~nm}$ is assigned to the enol tautomer, which is characterized by extended conjugation. Assuming that the keto form exists exclusively in basic media at a $\mathrm{pH}$ of 10 , as shown in Figure 4, the molar absorptivity of the keto tautomer was calculated to be $3.3 \times 10^{4} \mathrm{~L} / \mathrm{mol} \mathrm{cm}$. On the other hand, assuming that the enol form exists exclusively in an acidic medium at a $\mathrm{pH}$ of 4 , as shown in Figure 4, the molar absorptivity of the enol tautomer was calculated to be $2.25 \times 10^{4} \mathrm{~L} / \mathrm{mol} \mathrm{cm}$. These molar absorptivity values were applied to calculate the approximate ratios of both tautomers in organic solvents of different polarities (vide infra).

The emission spectra of both tautomers were recorded separately by adjusting both the medium acidity and excitation wavelengths. In a basic medium where the keto form is expected to dominate, fluorescence excitation at $400 \mathrm{~nm}$ gave a well-resolved, symmetrical fluorescence band around $500 \mathrm{~nm}$, as shown in Figure 5.

The excitation spectrum obtained after the emission maximum at $550 \mathrm{~nm}$ gave an excitation maximum at 


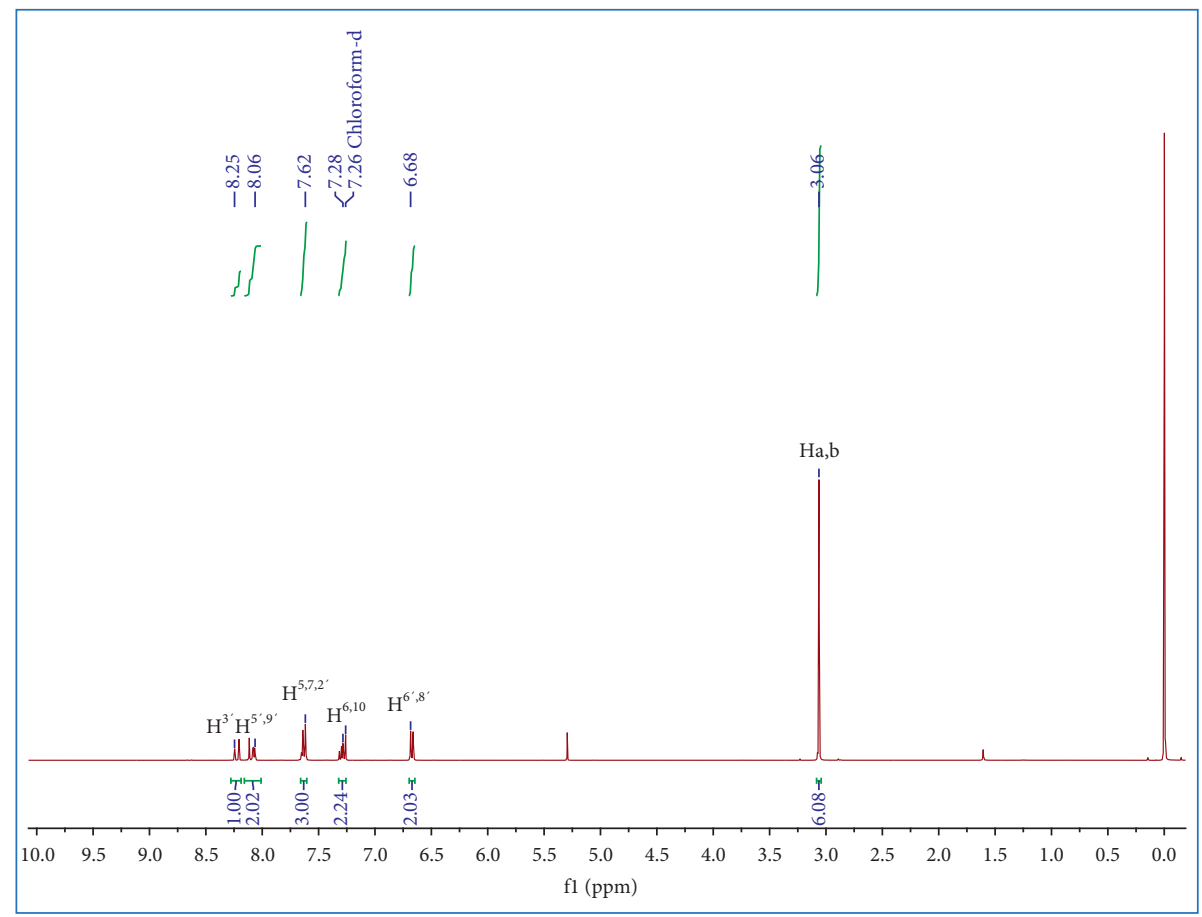

Figure 2: ${ }^{1} \mathrm{H}$ NMR spectrum $\left(400 \mathrm{MHz}, \mathrm{CDCl}_{3}\right)$ of coumarin 3.

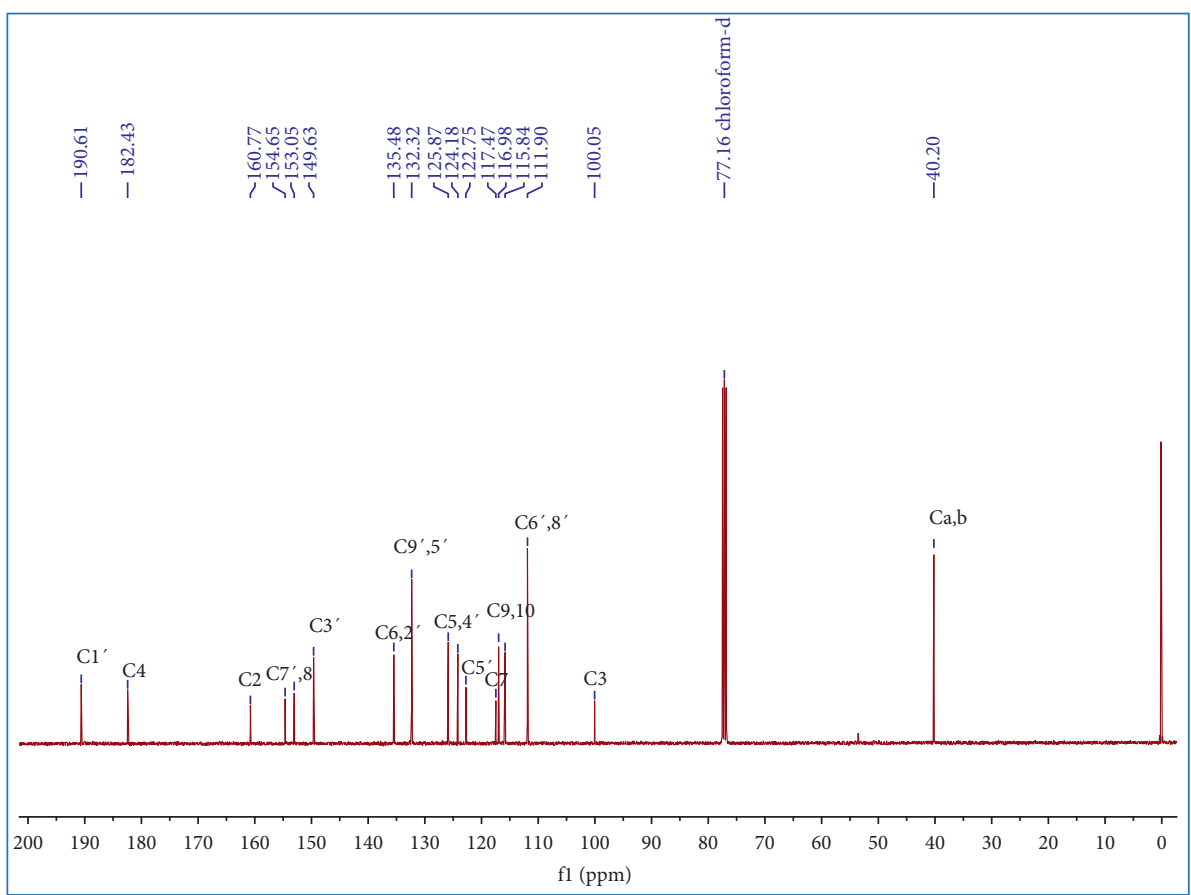

Figure 3: ${ }^{13} \mathrm{C}$ NMR spectrum $\left(100 \mathrm{MHz}, \mathrm{CDCl}_{3}\right)$ of coumarin 3.

$400 \mathrm{~nm}$, which coincides with the absorption spectrum of the keto form (Figure 4).

In an acidic medium where the enol form is expected to dominate, fluorescence excitation at $500 \mathrm{~nm}$ gave a structured fluorescence emission in the range of 570 to $800 \mathrm{~nm}$, as shown in Figure 6. The excitation spectrum obtained after the emission maximum at $650 \mathrm{~nm}$ gives an excitation spectrum with a strong maximum at $424 \mathrm{~nm}$ and a weaker band at $550 \mathrm{~nm}$. Both bands coincide with the absorption bands of the enol form.

A comparison of the fluorescence spectra of both tautomers of $\mathbf{3}$ shows that the keto tautomer, which prevails in 
<smiles>[CH]Oc1c(C(=O)/C=C/c2ccc(N(C)C)cc2)c(=O)oc2ccccc12</smiles>

(a)<smiles></smiles>

(b)

Scheme 3: Tautomeric forms of compound 3.

TABLE 1: Results of in vitro tests of the antimicrobial activities of coumarin derivatives 1 and 3.

\begin{tabular}{|c|c|c|c|c|c|c|c|c|c|c|c|c|c|c|c|}
\hline \multirow{2}{*}{$\begin{array}{l}\text { Bacteria } \\
\text { Conc. }(\mathrm{mg} / \mathrm{ml})\end{array}$} & \multicolumn{3}{|c|}{$\begin{array}{l}\text { Micrococcus luteus } \\
\quad \text { (LB 14110) }\end{array}$} & \multicolumn{3}{|c|}{$\begin{array}{c}\text { Listeria } \\
\text { monocytogenes } \\
\text { (ATCC 19117) }\end{array}$} & \multicolumn{3}{|c|}{$\begin{array}{c}\text { Staphylococcus } \\
\text { aureus (ATCC } \\
6538 \text { ) }\end{array}$} & \multicolumn{3}{|c|}{ E. coli } & \multicolumn{3}{|c|}{$\begin{array}{c}\text { Salmonella } \\
\text { typhimurium } \\
\text { (ATCC 1402) }\end{array}$} \\
\hline & 0.1 & 0.3 & 0.5 & 0.1 & 0.3 & 0.5 & 0.1 & 0.3 & 0.5 & 0.1 & 0.3 & 0.5 & 0.1 & 0.3 & 0.5 \\
\hline Derivative 1 & 15 & 13 & 12 & 11 & 14 & 17 & 14 & 13 & 10 & 11 & 12 & 13 & 14 & 15 & 16 \\
\hline Derivative 3 & 15 & 13 & 12 & 11 & 14 & 17 & 14 & 13 & 10 & 11 & 12 & 13 & 14 & 15 & 16 \\
\hline
\end{tabular}

TABLE 2: Minimal bacterial inhibitory concentrations (MICs) of $\mathbf{1}$, 3 , and ampicillin measured in $\mathrm{mg} / \mathrm{mL}$.

\begin{tabular}{lcc}
\hline Microorganism indicator & Compounds & $\begin{array}{c}\mathrm{MIC} \\
(\mathrm{mg} / \mathrm{mL})\end{array}$ \\
\hline \multirow{2}{*}{ Listeria monocytogenes (ATCC 19117) } & $\mathbf{1}$ & 1.235 \\
& $\mathbf{3}$ & 0.615 \\
& Ampicillin & 0.039 \\
\hline \multirow{2}{*}{ Salmonella typhimurium (ATCC 14028) } & $\mathbf{1}$ & 1.26 \\
& $\mathbf{3}$ & 0.040 \\
& Ampicillin & 0.6235 \\
\hline \multirow{2}{*}{ Micrococcus luteus } & $\mathbf{1}$ & 0.323 \\
& $\mathbf{3}$ & 0.314 \\
& Ampicillin & 0.0134 \\
\hline
\end{tabular}

TABLE 3: Acetylcholinesterase (AChE) inhibitor (AChEI) activities of the synthetic products.

\begin{tabular}{lc}
\hline $\begin{array}{l}\text { Synthetic } \\
\text { products }\end{array}$ & AChEI activities of the synthetical products \\
\hline 1 & $(\%)$ \\
3 & 35.2 \\
\hline
\end{tabular}

basic media, is characterized by a well-resolved, intense fluorescence peak, whereas the enol form that prevails in acidic media is characterized by structured, low-intensity fluorescence peaks. This is explained in terms of the amino nitrogen in the chalcone moiety of each tautomer, which causes a dual fluorescence quenching action. Specifically, the first quenching effect is due to the charge-transfer donoracceptor effect within the chalcone-coumarin system being reduced. The other quenching effect is a result of the aminonitrogen moiety being electron-withdrawing (due to its ability to be protonated) rather than electron-donating. It is well known that electron-donating groups enhance fluorescence, while electron-withdrawing groups quench fluorescence.

Figure 7 shows the change in fluorescence intensity $\left(\lambda_{\mathrm{ex}}=500 \mathrm{~nm}, \lambda_{\mathrm{em}}=550 \mathrm{~nm}\right)$ as a function of $\mathrm{pH}$. In acidic media, low fluorescence intensities were observed, and the

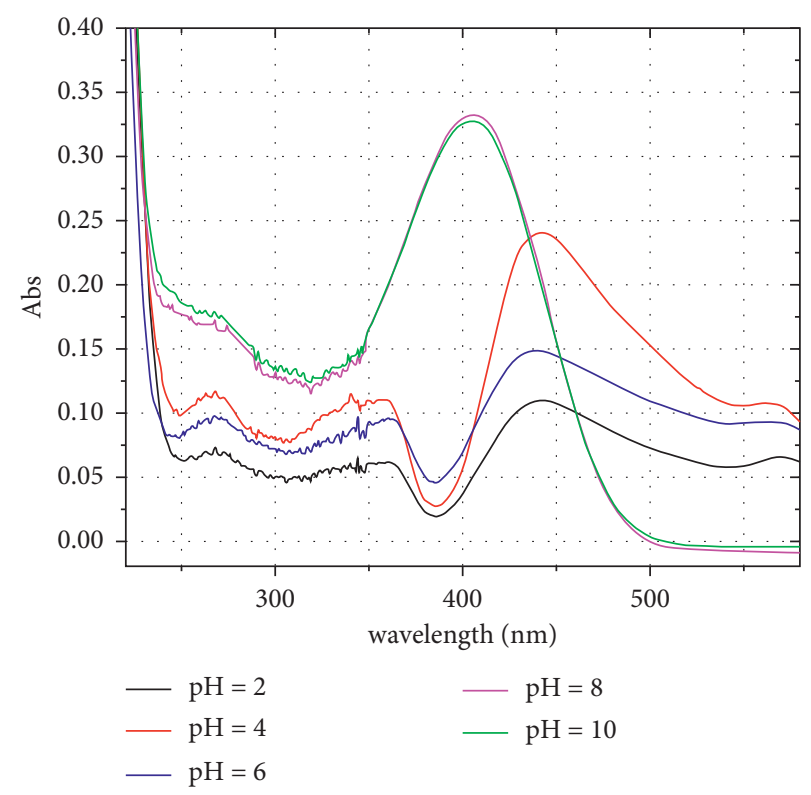

FIgURE 4: Absorption spectra of coumarin $3\left(1 \times 10^{-5} \mathrm{M}\right)$ in aqueous ethanolic solutions of different $\mathrm{pH}$ values.

fluorescence intensities increased as the medium basicity increased. From the plot of $\mathrm{pH}$ versus $\log \left[\left(\mathrm{A}_{\max }-\mathrm{A}\right) /\right.$ $\left.\left(A-A_{\min }\right)\right]$ (Figure 8), the conversion of the keto form to the enol form is most pronounced in a $10 \%$ aqueous ethanolicuniversal buffer solution with a $\mathrm{pH}$ of 6 .

3.4. Theoretical Calculations. The optimized structures together with the charge distribution for each atom in the optimized structure are illustrated for the two tautomers of coumarin 3 using the B3LYB/6-31G level of theory and the DFT method (Figure 9). The directions and relative magnitudes of the dipole moment for each tautomer were determined using the B3LYB/6-31G(d) level of theory. The lengths along the dipole-moment directions gave the relative magnitudes of the dipole moments for both tautomers. 


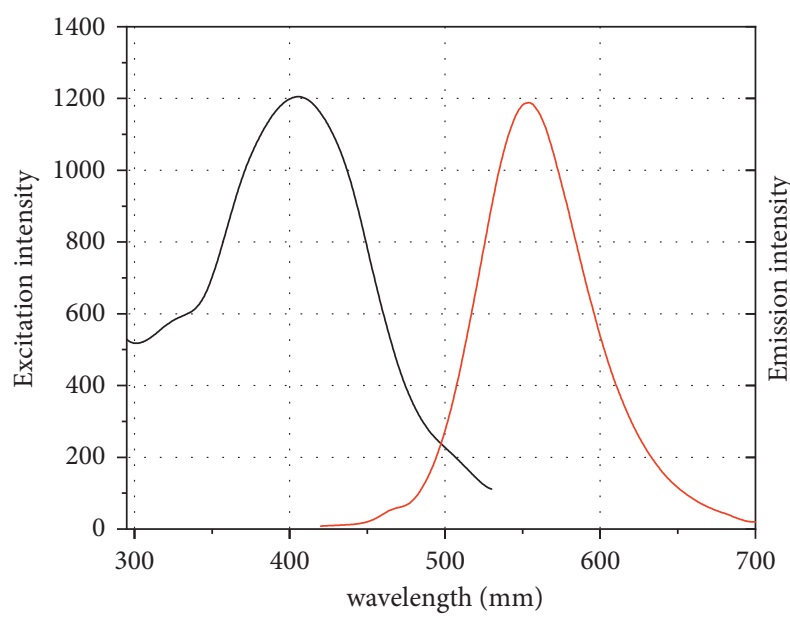

Figure 5: Emission (right; $\lambda_{\mathrm{ex}}=400 \mathrm{~nm}$ ) and excitation (left; $\left.\lambda_{\mathrm{em}}=550 \mathrm{~nm}\right)$ spectra of coumarin $3\left(1 \times 10^{-5} \mathrm{M}\right)$ in a $10 \%$ ethanolic-universal buffer solution with a $\mathrm{pH}$ of 10 .

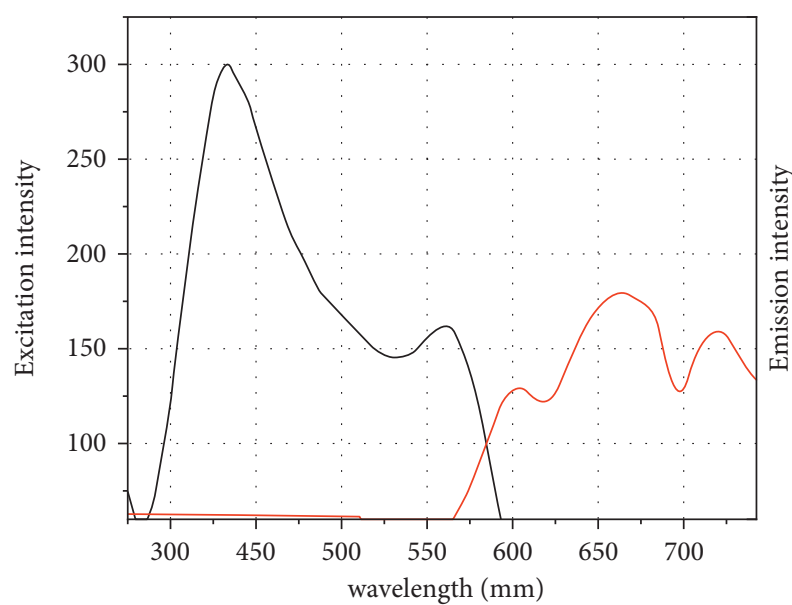

Figure 6: Emission (right; $\lambda_{\text {ex }}=500 \mathrm{~nm}$ ) and excitation (left; $\left.\lambda_{\mathrm{em}}=650 \mathrm{~nm}\right)$ spectra of coumarin $3\left(1 \times 10^{-5} \mathrm{M}\right)$ in a $10 \%$ ethanolic-universal buffer solution with a $\mathrm{pH}$ of 4 .

Selected bond lengths $(\AA)$, dihedral angles $\left({ }^{\circ}\right.$ ), and bond angles $\left({ }^{\circ}\right)$ for the gas-phase tautomers of coumarin $\mathbf{3}$ together with the calculated dipole moments of the tautomers are given in Table 4.

3.5. Solvent Effect Study. The emission and absorption spectra of coumarin 3 were measured in aqueous and organic solvents of different polarities $(\Delta f)$, as given by the following relation equation (1) [42]:

$$
\Delta f=\frac{(\varepsilon-1)}{(2 \varepsilon+1)}-\frac{\left(n^{2}-1\right)}{\left(4 n^{2}+2\right)},
$$

where $\varepsilon$ is the dielectric constant and $n$ is the refractive index of the solvent. Solvents of higher polarity are expected to enhance the formation of tautomers with higher dipole moments. The keto tautomer possesses a higher dipole moment value (6.19) than that of the enol form

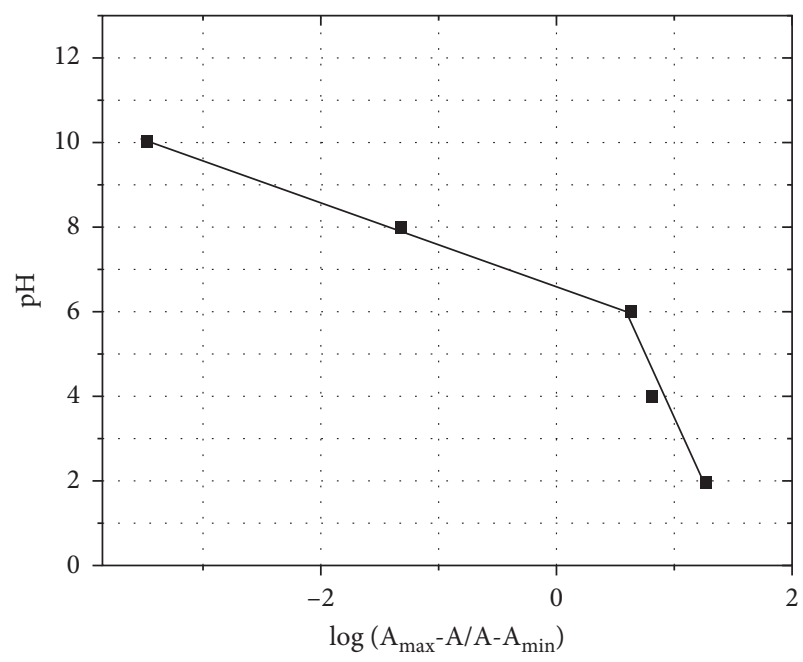

FIgURE 7: Curve demonstrating the fluorescence intensity of coumarin 3 as a function of $\mathrm{pH}$. Measured with coumarin 3 $\left(1 \times 10^{-5} \mathrm{M}\right)$ dissolved in a $10 \%$ ethanolic-universal buffer solution $\left(\lambda_{\mathrm{ex}}=500 \mathrm{~nm}, \lambda_{\mathrm{em}}=650 \mathrm{~nm}\right)$.

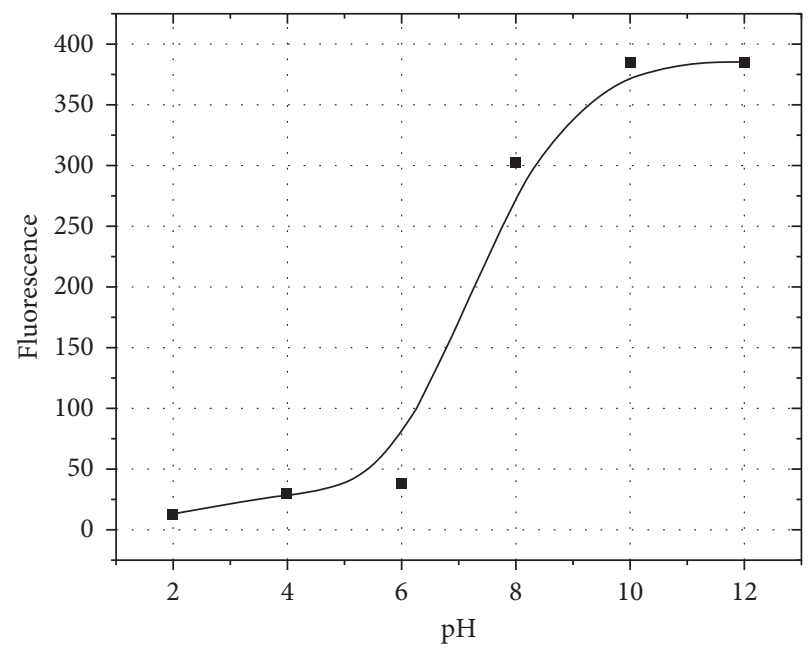

Figure 8: Plot of $\mathrm{pH}$ versus $\log \left[\left(\mathrm{A}_{\max }-\mathrm{A}\right) /\left(\mathrm{A}-\mathrm{A}_{\min }\right)\right]$ for coumarin 3 in a $10 \%$ aqueous ethanolic-universal buffer solution, which is most pronounced at a $\mathrm{pH}$ of 6 . Absorbance at $402 \mathrm{~nm}$ was monitored.

(3.85). This explains the increased amount of the keto form in polar solvents. Table 5 shows the keto/enol ratios when coumarin 3 is dissolved in organic solvents with different polarities and $\varepsilon$ values. It shows graphical representations of the increase in the keto/enol ratios as the solvent polarity increases. This was observed in both protic and aprotic solvents.

Solvent hydrogen bond donating parameter $\alpha$ [43] is another important factor that enhances the formation of the enol tautomer at the expense of the keto form. A linear correlation exists between the hydrogen bond donating parameter $\alpha$ of water (1.17), butanol (0.79), isopropanol (0.76), and acetonitrile (0.19). The enol form (\%) in these solvents were $21.7,16.5,16.5$, and $9.3 \%$ respectively (Figures 10 and 11). 
<smiles>[CH]Oc1c(C(=O)/C=C/c2ccc(N(C)C)cc2)c(=O)oc2ccccc12</smiles>

A

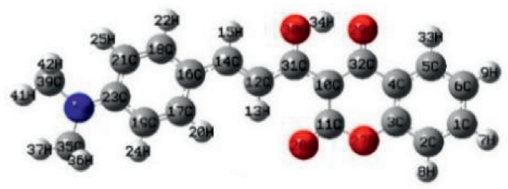

A<smiles>C/C=C/c1c(/C=C/c2ccc(N(C)C)cc2)c2ccccc2oc1=O</smiles>

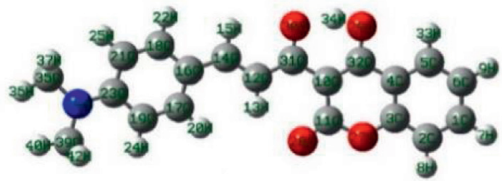

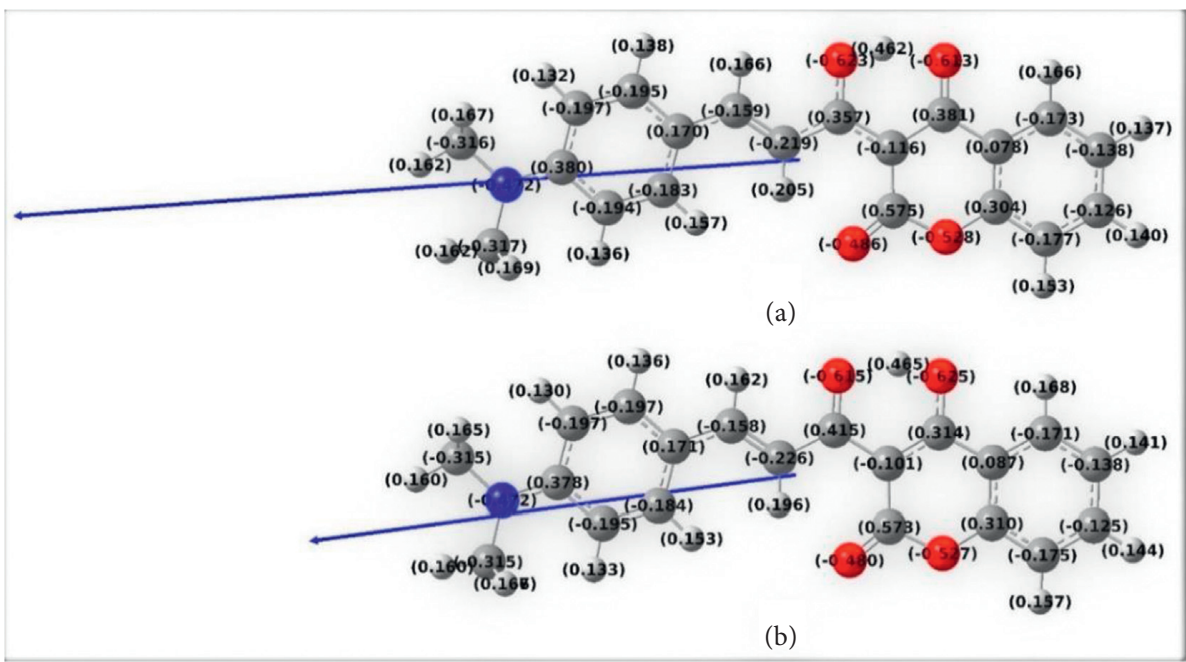

Figure 9: Optimized structures of the keto (A) and enol (B) tautomers of coumarin 3 and their charge distributions. The arrows indicate the direction of the dipole moment for each tautomer that was determined using the B3LYB/6-31G(d) level of theory. The lengths along the dipole-moment directions give the relative magnitudes of dipole moments for both tautomers.

TABLE 4: Selected bond lengths $(\AA)$, dihedral angles $\left({ }^{\circ}\right)$, and bond angles $\left(^{\circ}\right)$ for the gas-phase tautomers of coumarin 3 , as calculated with the B3LYP/6-31G(d) level of theory.

\begin{tabular}{lcr}
\hline Parameters & A Form & B Form \\
\hline Bond length $(\AA)$ & & 1.028 \\
O30-H34 & 1.493 & 1.461 \\
O29-H34 & 1.319 & 1.041 \\
O30-C31 & 1.428 & 1.266 \\
C31-C10 & 1.448 & 1.477 \\
C10-C32 & 1.261 & 1.404 \\
C32-O29 & 1.214 & 1.313 \\
C11-O28 & 1.395 & 1.211 \\
C11-O27 & 1.375 & 1.402 \\
C23-N26 & 1.362 & 1.377 \\
C12-C14 & & 1.358 \\
\hline Bond Angle $\left(^{\circ}\right)$ & 153.41 & 152.86 \\
O30-H34-O29 & 118.08 & 117.76 \\
C31-C10-C32 & 123.35 & 123.40 \\
C11-O27-C3 & 114.75 & 114.76 \\
O28-C11-C27 & 126.96 & 127.39 \\
C12-C14-C16 & \\
\hline
\end{tabular}


TABle 4: Continued.

\begin{tabular}{lcc}
\hline Parameters & A Form & B Form \\
\hline C39-N26-O35 & 119.60 & 121.24 \\
\hline Dihedral angle $\left(^{\circ}\right)$ & & \\
C39-N26-C23-C19 & 179.99 & 179.97 \\
C21-C23-N26-O35 & 179.98 & 179.97 \\
H34-O30-C31-C12 & 179.99 & 179.99 \\
O29-C30-C10-C11 & 179.99 & 179.99 \\
C32-C10-C11-O28 & 179.97 & 180.00 \\
C5-C4-C3-O27 & 179.99 & 179.99 \\
Dipole moment (D) & 6.19 & 3.85 \\
\hline
\end{tabular}

TABLE 5: The ketol/enol ratios when coumarin 3 was dissolved in solvents with different polarities and dielectric constants $(\varepsilon)$.

\begin{tabular}{|c|c|c|c|c|}
\hline Solvent & Dielectric constant (D) & $\Delta f$ & Enol form (\%) & Keto form (\%) \\
\hline$n$-hexane & 1.9 & 0.13 & 83.0 & 17.0 \\
\hline$n$-heptane & 1.9 & 0.12 & 90.6 & 9.4 \\
\hline cyclohexane & 2.0 & 0.15 & 91.0 & 9.0 \\
\hline dioxane & 2.2 & 0.12 & 93.8 & 6.2 \\
\hline $\mathrm{CCl}_{4}$ & 2.2 & 0.12 & 92.8 & 7.2 \\
\hline benzene & 2.3 & 0.12 & 90.4 & 9.6 \\
\hline $\mathrm{CHCl}_{3}$ & 4.8 & 0.25 & 87.3 & 12.7 \\
\hline $\mathrm{CH}_{2} \mathrm{Cl}_{2}$ & 9.1 & 0.32 & 70.0 & 30.0 \\
\hline $\mathrm{BuOH}$ & 17.8 & 0.36 & 83.5 & 16.5 \\
\hline IsoPrOH & 18.3 & 0.37 & 83.5 & 16.5 \\
\hline $\mathrm{EtOH}$ & 24.6 & 0.38 & 60.9 & 39.1 \\
\hline EG & 31.7 & 0.30 & 38.9 & 61.1 \\
\hline $\mathrm{MeOH}$ & 32.6 & 0.39 & 61.0 & 39.0 \\
\hline $\mathrm{ACN}$ & 35.9 & 0.39 & 90.7 & 9.3 \\
\hline DMF & 38.3 & 0.38 & 46.1 & 53.9 \\
\hline Acetone & 39.3 & 0.28 & 72.6 & 27.4 \\
\hline Glycerol & 42.5 & 0.32 & 64.3 & 35.7 \\
\hline DMSO & 46.5 & 0.37 & 9.7 & 90.3 \\
\hline $\mathrm{H}_{2} \mathrm{O}$ & 78.4 & 0.36 & 78.3 & 21.7 \\
\hline
\end{tabular}

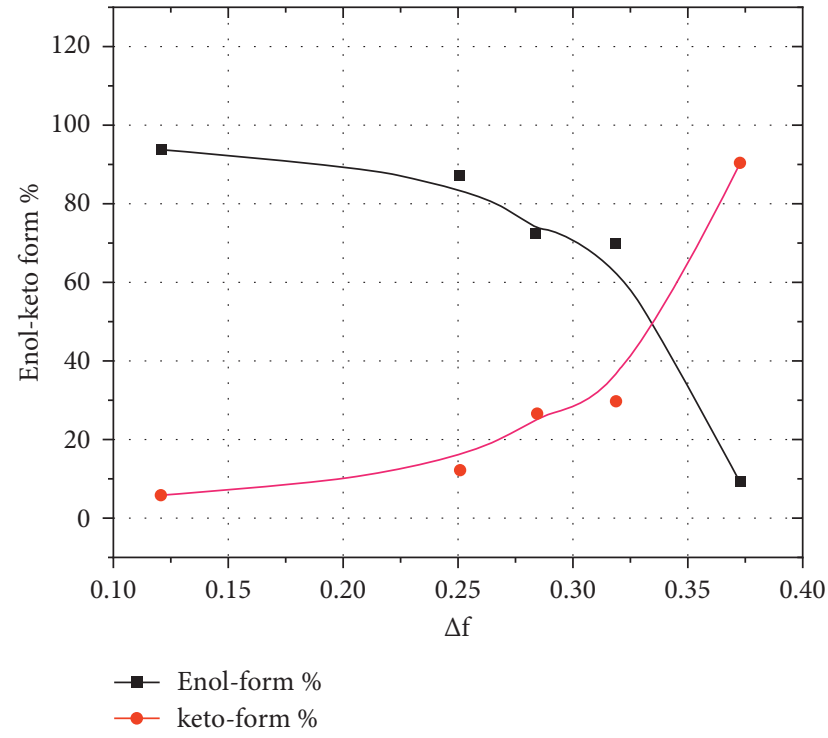

(a)

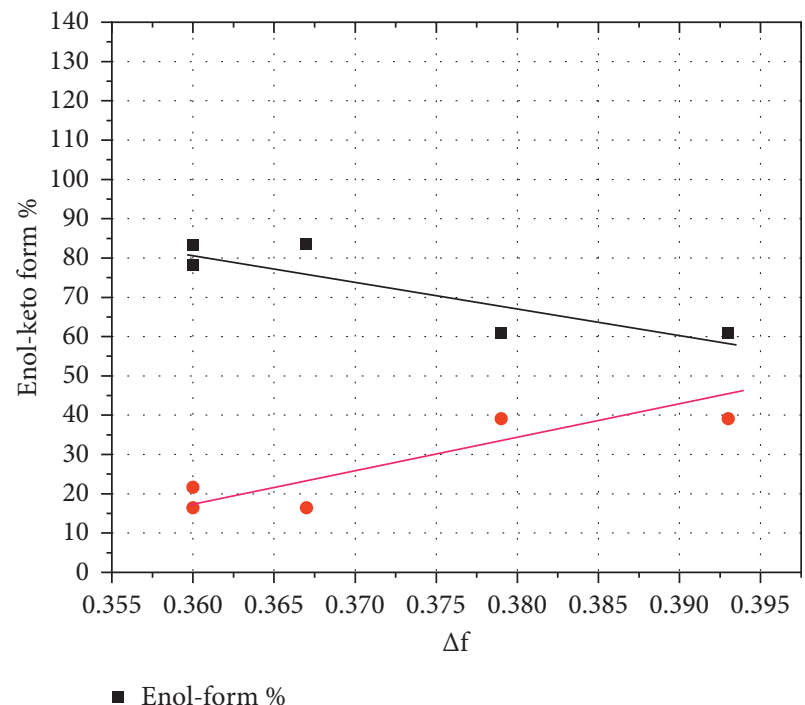

- Enol-form \%

- keto-form \%

(b)

Figure 10: Changes in the keto/enol ratios of coumarin 3 as a function of solvent polarity for aprotic (a) and protic (b) solvents. 


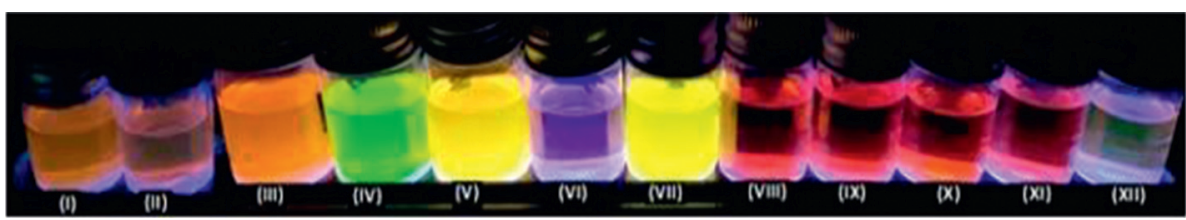

Figure 11: Color display of coumarin 3 emission under a $365 \mathrm{~nm}$ UV-torch in solvents of different polarities: (I) THF, (II) CCl $\mathrm{CH}_{2} \mathrm{Cl}_{2}$, (IV) $\mathrm{C}_{4} \mathrm{H}_{9} \mathrm{Cl}$, (V) $\mathrm{CHCl}_{3}$, (VI) EG, (VII) 1,4-dioxane, (VIII) $\mathrm{CH}_{3} \mathrm{CN}$, (IX) DMF, (X) acetone, (XI) $\mathrm{CH}_{3} \mathrm{OH}$, and (XII) $\mathrm{C}_{2} \mathrm{H}_{5} \mathrm{OH}$.

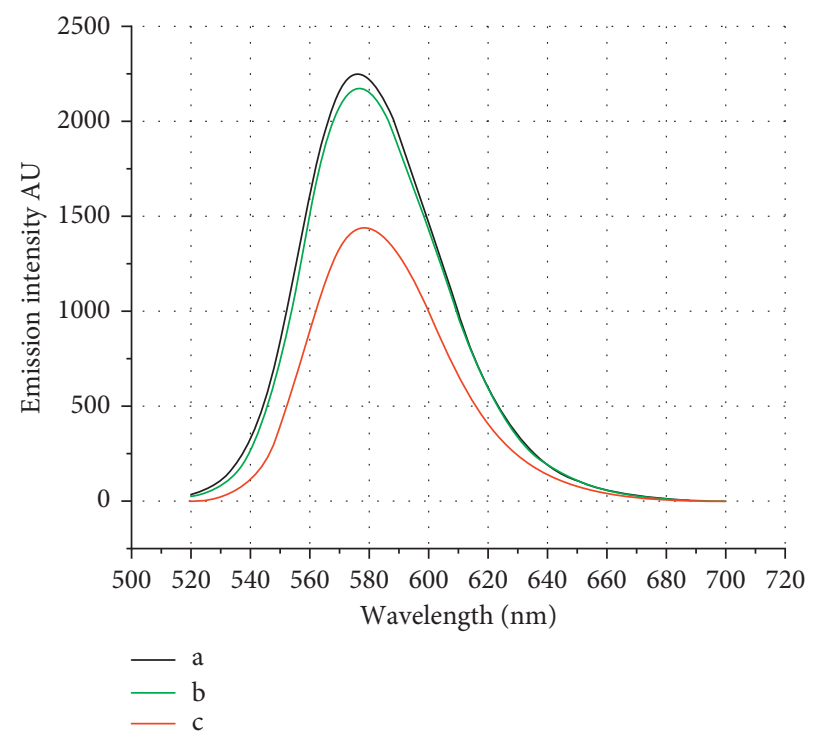

Figure 12: Emission spectra $\left(\lambda_{\mathrm{ex}}=500 \mathrm{~nm}\right)$ of coumarin $3\left(3 \times 10^{-6} \mathrm{M}\right)$ in ethanol (a), flushed with $\mathrm{O}_{2}$ for 10 min (b), and flushed with $\mathrm{N}_{2}$ for $10 \min (\mathrm{c})$.

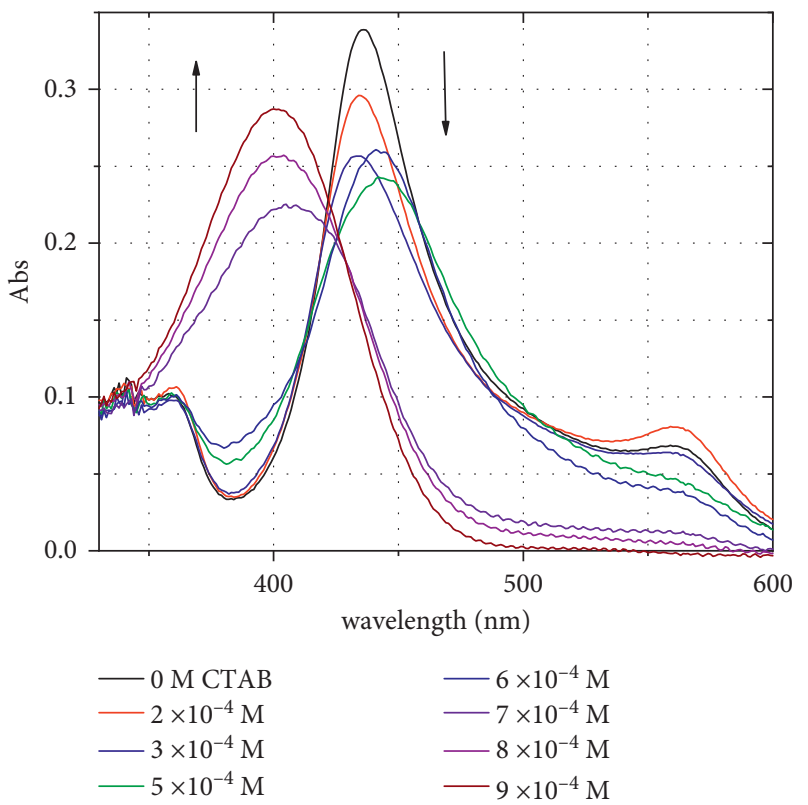

FIGURE 13: Absorption spectra of coumarin $3\left(1 \times 10^{-5} \mathrm{M}\right)$ in $10 \%$ ethanolic aqueous solutions with increasing cetyl trimethyl ammonium bromide (CTAB) concentrations.

3.6. Effect of Molecular Oxygen on Fluorescence Efficiency. Coumarin 3 fluorescence was found to be reversible upon quenching by molecular oxygen (Figure 12). Molecular oxygen is a paramagnetic species, and its presence in the medium increases the rate of intersystem crossing (isc) at the expense of molecular fluorescence. Figure 12 shows 


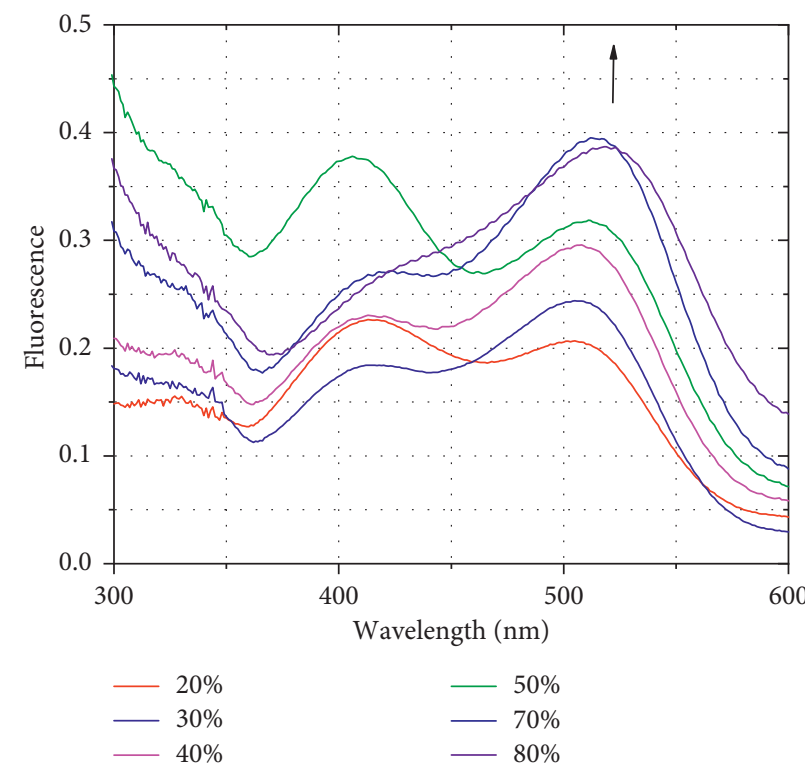

(a)

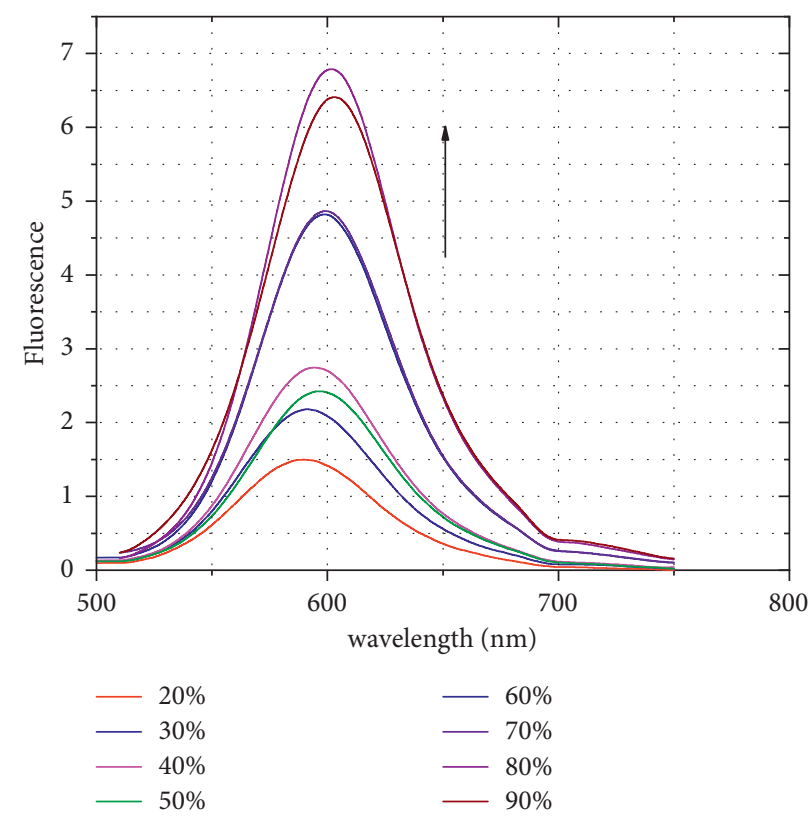

(b)

FIgURE 14: Fluorescence spectra $\left(\lambda_{\mathrm{ex}}=500 \mathrm{~nm}\right)$ of coumarin $3\left(1 \times 10^{-5} \mathrm{M}\right)$ in $10 \%$ ethanolic aqueous solutions (a) and its fluorescence intensity (b) with increasing sodium dodecyl sulfate (SDS) concentrations.

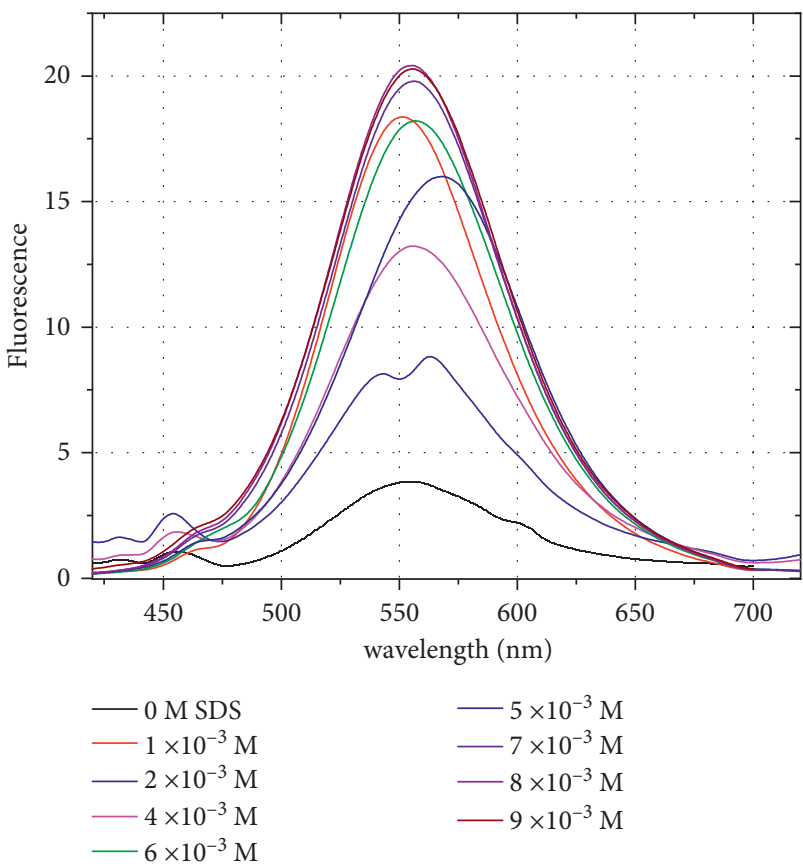

(a)

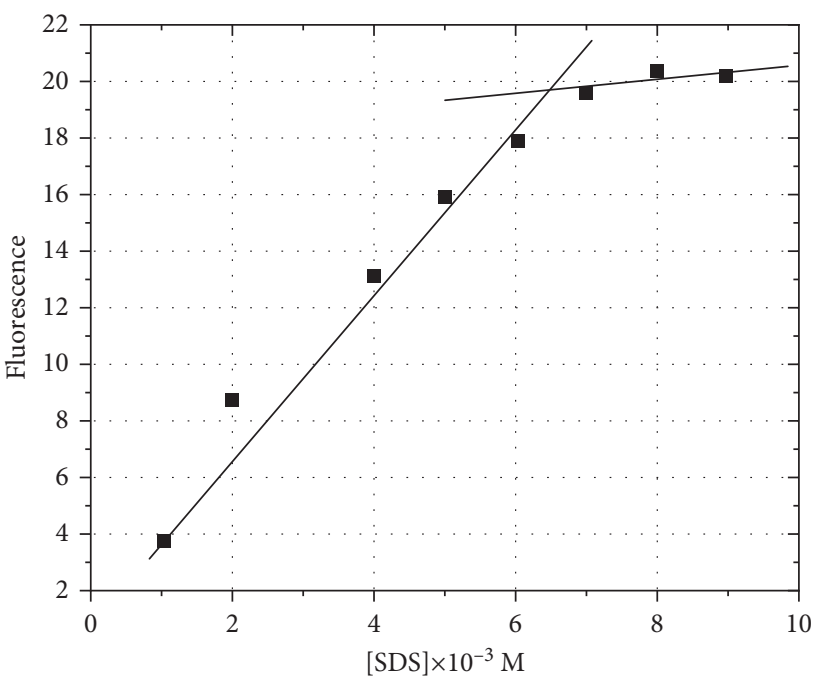

(b)

FIGURE 15: Absorption spectra (a) and fluorescence spectra $\left(\lambda_{\text {ex }}=500 \mathrm{~nm}\right)(\mathrm{b})$ of coumarin $3\left(1 \times 10^{-5} \mathrm{M}\right)$ in ethanol/glycerol mixtures with different glycerol concentrations.

that the original fluorescence was nearly recovered upon the deoxygenation of the ethanolic medium via nitrogen flushing. This reversible fluorescence quenching by molecular oxygen could allow coumarin 3 to be used to determine the accessibility of oxygen to regions of macromolecules surrounding intrinsic or bound fluorophores, and to probe structural fluctuations in macromolecules [44]. 


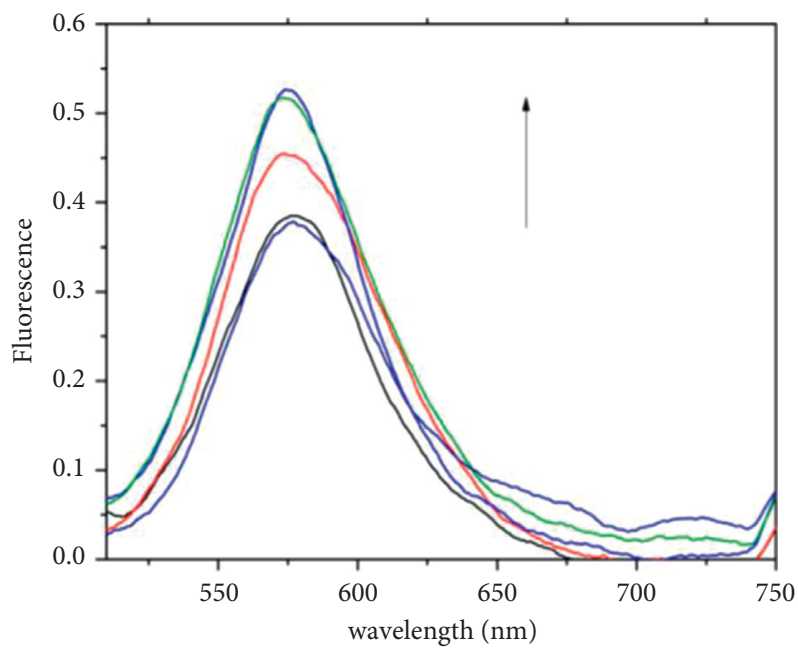

Figure 16: Emission spectra $\left(\lambda_{\mathrm{ex}}=500 \mathrm{~nm}\right)$ of coumarin $3\left(1 \times 10^{-5} \mathrm{M}\right)$ in the presence of different concentrations of DNA in a $0.1 \mathrm{M}$ Tris$\mathrm{HCl}$ buffer. The DNA concentrations used to obtain the different fluorescence intensities at $575 \mathrm{~nm}$ are 0.400 (dark blue), 0.550 (black), 0.700 (red), 0.900 (green), and $1.100 \mu \mathrm{g} / \mathrm{mL}$ (light blue).

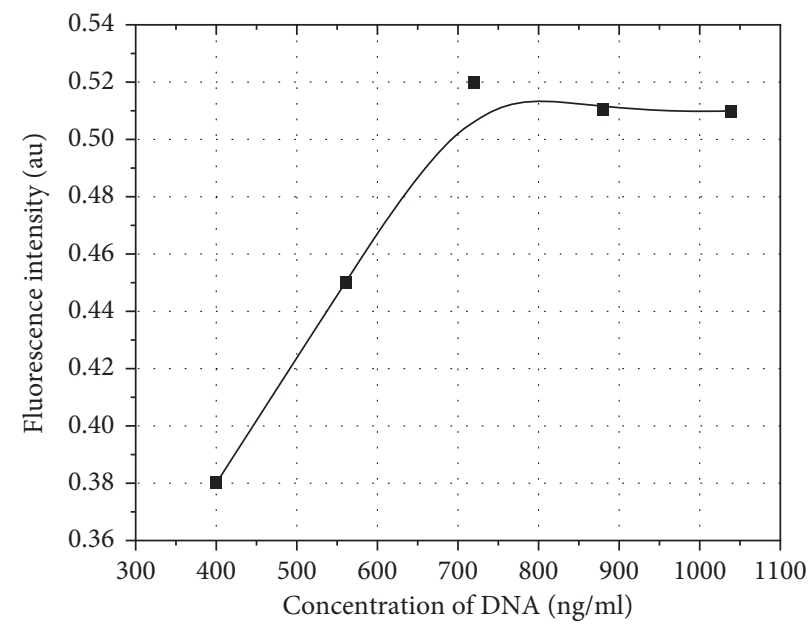

FIGURE 17: Emission spectra of coumarin $3\left(1 \times 10^{-5} \mathrm{M}\right)$ in the presence of different concentrations of DNA in a $0.1 \mathrm{M}$ Tris- HCl buffer.
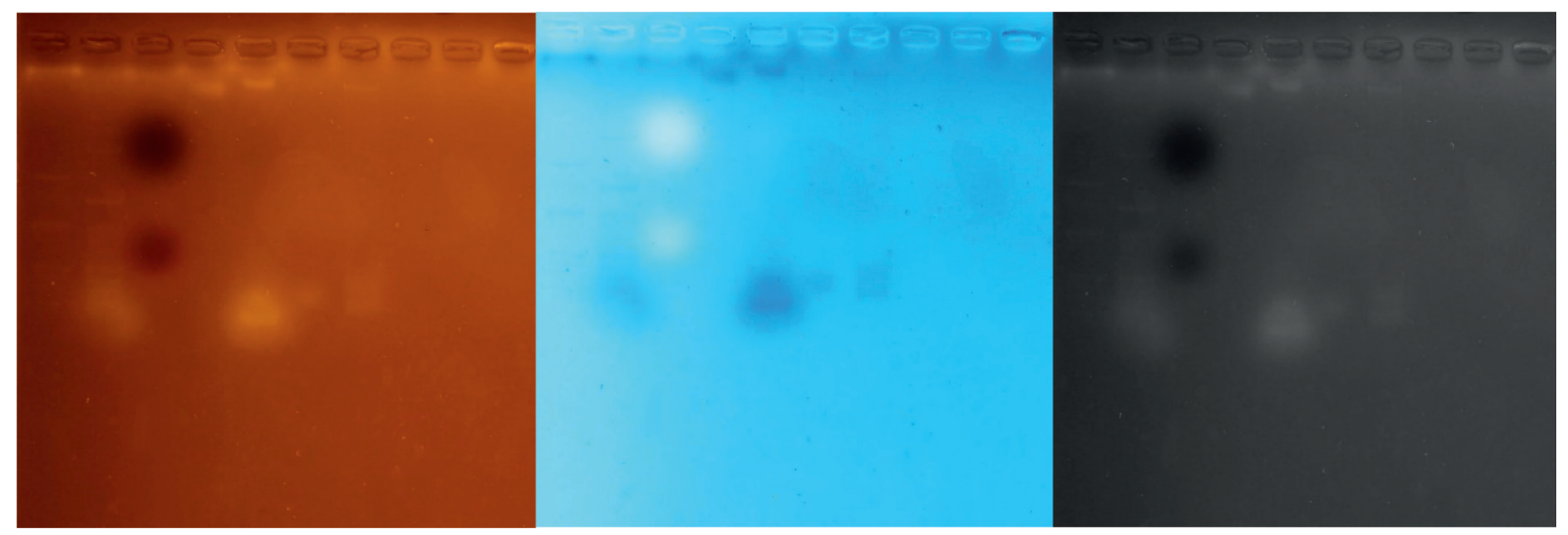

FIgURE 18: Gel electrophoresis of DNA fragments using coumarin 3 as a fluorescent stain dye. 


\subsection{Effect of Microenvironment on Fluorescence Efficiency}

3.7.1. Effect of Surfactants. Coumarin 3 undergoes solubilization in the presence of both anionic (sodium dodecyl sulfate; SDS) and cationic (cetyl trimethyl ammonium bromide; CTAB) surfactants. Figure 13 shows the change in the absorption spectra of coumarin $3\left(1 \times 10^{-5} \mathrm{M}\right)$ as a function of the CTAB concentration. As the $\mathrm{CTAB}$ concentration increases, the keto tautomer concentration increases at the expense of the enol form, whereby a nonsharp isosbestic point is obtained at approximately $425 \mathrm{~nm}$. The appearance of an isosbestic point is an indication of keto and enol tautomers being the two main species in which coumarin 3 exists.

The solubilization of coumarin 3 in anionic SDS in 10\% ethanolic aqueous solutions occurs with the keto-form absorbance at $400 \mathrm{~nm}$ increasing as the SDS surfactant concentration increases. The keto form fluorescence at $550 \mathrm{~nm}$ $\left(\lambda_{\text {ex }}=500 \mathrm{~nm}\right)$ also increased as the SDS surfactant concentration increased, as shown in Figure 14(a). The fluorescence intensity-SDS concentration plot (Figure 14(b)) shows a break at an SDS concentration of $6.25 \times 10^{-3} \mathrm{M}$, which is close to the SDS critical micelle concentration (CMC) of $8.5 \times 10^{-3} \mathrm{M}$. Earlier reports have indicated that the CMC of aqueous SDS decreases with the addition of $10 \%$ ethanol [45].

3.7.2. Effect of Medium Viscosity. Figure 15 shows both the absorption and emission spectra of coumarin 3 in ethanol/ glycerol mixtures with different glycerol concentrations. The fluorescence efficiency is enhanced upon increasing the medium viscosity owing to the imposed molecular rigidity in the viscous medium. This is attributed to the suppression of nonradiation photophysical pathways in the form of internal conversion (ic) and vibrational cascade (vc) [21].

3.7.3. Coumarin 3-DNA Interactions. In the $\mathrm{pH}$ range of 5 to 9 , common nucleic acid duplexes are quite stable. Below $\mathrm{pH}$ 5 and above $\mathrm{pH} \mathrm{9,} \mathrm{standard} \mathrm{duplexes} \mathrm{are} \mathrm{destabilized} \mathrm{be-}$ cause of the titration of the polar groups on the bases. Polar groups are involved in the hydrogen bonding between DNA base pairs, and ionization adds a net charge to the polar bonds [46]. A solution of DNA was prepared in a $0.1 \mathrm{M}$ Tris $\mathrm{HCl}$ buffer. The buffer was prepared in distilled water, and its $\mathrm{pH}$ was adjusted to 7 by the addition of $\mathrm{NaOH}(0.1 \mathrm{M})$. The fluorescence intensity of coumarin 3 at $575 \mathrm{~nm}$ increased with increasing DNA concentration, as shown in Figures 16 and 17.

Emission spectra of coumarin $3\left(1 \times 10^{-5} \mathrm{M}\right)$ in the presence of different concentrations of DNA in a $0.1 \mathrm{M}$ Tris$\mathrm{HCl}$ buffer were collected, and it was observed that the fluorescence intensity was lower at higher DNA concentrations (about $1.20 \mu \mathrm{g} / \mathrm{mL}$ ). This is presumably due to the consumption of $\mathrm{HCl}$ via its binding to the DNA bases and the concomitant formation of the keto form of 3 . A solution of 3 in a $0.1 \mathrm{M}$ Tris $\mathrm{HCl}$ buffer was tested as a DNA

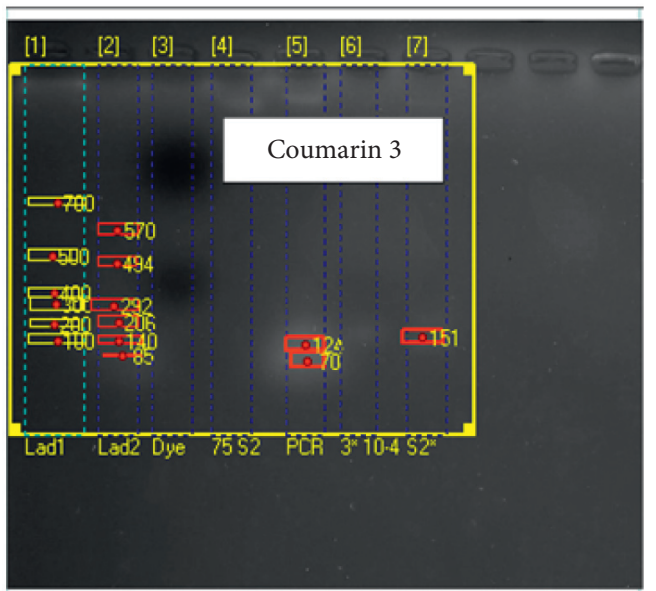

FIgURE 19: Analysis sheet of the gel electrophoresis technique of DNA fragments using coumarin $\mathbf{3}$ as a fluorescent stain dye.

TABLE 6: Analysis data of the gel electrophoresis technique of DNA fragments using coumarin 3.

\begin{tabular}{lccccc}
\hline Lane & Band & Area & Volume & Size & Sample ID \\
\hline 5 & 13 & 2025 & 421694 & 124 & PCR sample \\
5 & 14 & 1943 & 3653737 & 70 & PCR sample \\
7 & 15 & 2187 & 1407334 & 151 & $S_{2}^{*}$ (ladder-stained sample) \\
\hline
\end{tabular}

fluorescent stain using gel electrophoresis (see Figures 18 and 19 and Table 6).

\section{Conclusion}

A new and easy-to-prepare coumarin derivative, (E)-3-(3(4-(dimethylamino)phenyl)acrylo-yl)-4-hydroxy- $2 \mathrm{H}$-chromen-2-one (3), was synthesized. When compared to another coumarin derivative (1) and ampicillin (a commonly used standard), coumarin 3 exhibited the highest activity against the Gram-negative bacterium Salmonella typhimurium (ATCC14028). Coumarin 3 also showed the highest AChEI activity (48.25\% inhibition) among the three compounds. This newly designed molecule (3) benefits from the bioactivity of both its coumarin and chalcone moieties and simultaneously exploits the ability of its chalcone moiety to act as a built-in probe for assessing microenvironments and interactions with DNA molecules.

Spectral studies together with quantum mechanical calculations revealed that coumarin $\mathbf{3}$ predominantly exists as keto and enol tautomers, with the keto form having a higher dipole moment than that of the enol form. The keto/ enol ratios of coumarin $\mathbf{3}$ in both protic and aprotic solvents with different polarities and $\varepsilon$ values were calculated, where keto-tautomer formation was found to be enhanced upon increasing the polarity of the protic and aprotic solvents in basic and micellar media. Enhanced fluorescence of coumarin 3 in glycerol/ethanol mixtures was observed upon increasing the medium viscosity. This was ascribed to molecular rigidity, which typically occurs when high viscosities are employed. This criterion was further investigated in DNA solutions, whereby coumarin 3 showed enhanced 
fluorescence upon its uptake in DNA grooves and was therefore tested as a novel DNA fluorescent stain. Finally, gel electrophoresis was carried out, whereby enhanced fluorescence was observed in the DNA regions. We suggest molecular docking against DNA gyrase inhibitory activity.

\section{Data Availability}

Data used to support the findings of this study are available from the corresponding author upon request.

\section{Additional Points}

Experimental details, chemical and solutions, apparatus and measurements, and preparation of samples.

\section{Disclosure}

The funders had no role in the design of the study; in the collection, analyses, or interpretation of the data; in the writing of the manuscript; or in the decision to publish the results.

\section{Conflicts of Interest}

The authors declare no conflicts of interest.

\section{Acknowledgments}

The researchers would like to thank the Deanship of Scientific Research, Qassim University for funding the publication of this project.

\section{References}

[1] A. M. Hamdy, Z. Khaddour, N. A. Al-Masoudi et al., "Synthesis of arylated coumarins by Suzuki-Miyaura cross-coupling. Reactions and anti-HIV activity," Bioorganic \& Medicinal Chemistry, vol. 24, no. 21, pp. 5115-5126, 2016.

[2] S. N. Mangasuli, K. M. Hosamani, H. C. Devarajegowda, M. M. Kurjogi, and S. D. Joshi, "Synthesis of coumarintheophylline hybrids as a new class of anti-tubercular and anti-microbial agents," European Journal of Medicinal Chemistry, vol. 146, pp. 747-756, 2018.

[3] K. Kasperkiewicz, M. B. Ponczek, J. Owczarek, P. Guga, and E. Budzisz, "Antagonists of vitamin K-popular coumarin drugs and new synthetic and natural coumarin derivatives," Molecules, vol. 25, no. 6, p. 1465, 2020.

[4] E. Küpeli Akkol, Y. Genç, B. Karpuz, E. Sobarzo-Sánchez, and R. Capasso, "Coumarins and coumarin-related compounds in pharmacotherapy of cancer," Cancers, vol. 12, no. 7, pp. 1959-1984, 2020.

[5] M. Gellert, M. H. O'Dea, T. Itoh, and J. Tomizawa, "Novobiocin and coumermycin inhibit DNA supercoiling catalyzed by DNA gyrase," Proceedings of the National Academy of Sciences, vol. 73, no. 12, pp. 4474-4478, 1976.

[6] A. Thakur, R. Singla, and V. Jaitak, "Coumarins as anticancer agents: a review on synthetic strategies, mechanism of action and SAR studies," European Journal of Medicinal Chemistry, vol. 101, pp. 476-495, 2015.

[7] H.-N. LV, S. Wang, K.-W. Zeng et al., "Anti-inflammatory coumarin and benzocoumarin derivatives from Murraya alata," Journal of Natural Products, vol. 78, no. 2, pp. 279-285, 2015.

[8] J. Wu, Y. Liao, and Z. Yang, "Synthesis of 4-substituted coumarins via the palladium-catalyzed cross-couplings of 4tosylcoumarins with terminal acetylenes and organozinc reagents," Journal of Organic Chemistry, vol. 66, no. 10, pp. 3642-3645, 2001.

[9] S. Singla and P. Piplani, "Coumarin derivatives as potential inhibitors of acetylcholinesterase: synthesis, molecular docking and biological studies," Bioorganic \& Medicinal Chemistry, vol. 24, no. 19, pp. 4587-4599, 2016.

[10] T. Nehybova, J. Smarda, L. Daniel, J. Brezovsky, and P. Benes, "Wedelolactone induces growth of breast cancer cells by stimulation of estrogen receptor signalling," The Journal of Steroid Biochemistry and Molecular Biology, vol. 152, pp. 76-83, 2015.

[11] K. V. Sashidhara, R. K. Modukuri, S. Singh et al., "Design and synthesis of new series of coumarin-aminopyran derivatives possessing potential anti-depressant-like activity," Bioorganic \& Medicinal Chemistry Letters, vol. 25, no. 2, pp. 337-341, 2015.

[12] K. Kinga, E.-P. Anna, and B. Elzbieta, "Sunscreening and photosensitizing properties of coumarins and their derivatives," Letters in Drug Design and Discovery, vol. 13, pp. 465-474, 2016.

[13] B.-C. Lee, S. Y. Lee, H. J. Lee et al., "Anti-oxidative and photoprotective effects of coumarins isolated fromFraxinus chinensis," Archives of Pharmacal Research, vol. 30, no. 10, pp. 1293-1301, 2007.

[14] D. Bensalah, A. Mnasri, A. Chakchouk-Mtibaa, L. Mansour, L. Mellouli, and N. Hamdi, "Synthesis and antioxidant properties of some new thiazolyl coumarin derivatives," Green Chemistry Letters and Reviews, vol. 13, no. 2, pp. 155-163, 2020.

[15] C. Mhiri, L. Boubakri, R. Ternane et al., "Three-component, one-pot synthesis of pyrano[3,2-c]chromene derivatives catalyzed by ammonium acetate: synthesis, characterization, cation binding, and biological determination," Journal of Heterocyclic Chemistry, vol. 57, no. 1, pp. 291-298, 2019.

[16] S. J. Bullock, C. E. Felton, R. V. Fennessy et al., "Coumarinbased luminescent ligand that forms helicates with dicationic metal ions," Dalton Transactions, vol. 47, pp. 10570-10573, 2009.

[17] B. Z. Kurt, N. O. Kandas, A. Dag, F. Sonmez, and M. Kucukislamoglu, "Synthesis and biological evaluation of novel coumarin-chalcone derivatives containing urea moiety as potential anticancer agents," Arabian Journal of Chemistry, vol. 13, no. 1, pp. 1120-1129, 2017.

[18] M. Pietrzak, M. Józefowicz, A. Bajorek, and J. R. Heldt, "Experimental and theoretical studies of the spectroscopic properties of chalcone derivatives," Journal of Fluorescence, vol. 27, no. 2, pp. 537-549, 2017.

[19] S. A. El-Daly, E.-Z. M. Ebied, and G. Duportail, "Spectral, lifetime and photochemical characteristics of 4-acetoxychalcone in viscous media," Spectrochimica Acta Part A: Molecular Spectroscopy, vol. 50, no. 7, pp. 1227-1233, 1994.

[20] M. Maus, W. Rettig, D. Bonafoux, and R. Lapouyade, "Photoinduced intramolecular charge transfer in a series of differently twisted Donor-Acceptor biphenyls as revealed by fluorescence," The Journal of Physical Chemistry A, vol. 103, no. 18, pp. 3388-3401, 1999.

[21] E. M. Ebeid and S. M. AlHazmy, Photophysical and LaserBased Techniques in Chemistry, Biology and Medicine Chapter 4.22, BookSurge, Charleston, SC, USA, 2006. 
[22] H. Wei, J. Ruanb, and X. Zhang, "Coumarin-chalcone hybrids: promising agents with diverse pharmacological properties," RSC Advances, vol. 6, p. 10846, 2016.

[23] F. Pérez-Cruz, S. Vazquez-Rodriguez, M. João Matos et al., "Synthesis and electrochemical and biological studies of novel coumarin-chalcone hybrid compounds," Journal of Medicinal Chemistry, vol. 56, pp. 6136-6145, 2013.

[24] A. Kumar and S. Kumar, "Coumarin-chalcone hybrids for biological potentials: a strategy of molecular hybridization for drug design," International Journal of Pharmaceutical Sciences Review and Research, vol. 64, no. 2, pp. 146-151, 2020.

[25] S. D. Kudale and M. N. Deodhar, "Synthesis and evaluation of some coumarin containing potential antimicrobial agents," $E$ Journal of Chemistry, vol. 9, no. 4, pp. 2493-2500, 2012.

[26] L. Santana, Y. Santos, S. Serra, and S. Vazquez-Rodrigu, "Efficient synthesis of coumarin-chalcones hybrids as new scaffold with antibacterial interest," in Proceedings of the MDPI in the 14th International Electronic Conference on Synthetic Organic Chemistry, Spain, November 2010.

[27] K. V. Sashidhara, A. Kumar, M. Kumar, J. Sarkar, and S. Sinha, "Synthesis and in vitro evaluation of novel coumarin-chalcone hybrids as potential anticancer agents," Bioorganic \& Medicinal Chemistry Letters, vol. 24, pp. 72057211, 2010.

[28] S. Vazquez-Rodriguez, M. J. Matos, R. F. Guíñez et al., "Coumarin-chalcone derivatives as potential antitrypanosomal and antioxidant compounds," in Proceedings of the 16th International Conference on Synthetic Organic Chemistry (ECSOC-16), Spain, November 2012.

[29] L. Kang, X. H. Gao, H. R. Liu et al., "Structure activity relationship investigation of coumarin-chalcone hybrids with diverse side-chains as acetylcholinesterase and butyrylcholinesterase inhibitors," Molecular Diversity, vol. 22, pp. 893-906, 2018.

[30] S. Vazquez-Rodriguez, R. F. Guíñez, M. J. Matos et al., "Synthesis and trypanocidal properties of new coumarinchalcone derivatives," Medicinal Chemistry, vol. 5, no. 4, pp. 173-177, 2015.

[31] M. Frisch and F. Clemente, Gaussian 09, Revision A. 01, M. J. Frisch, G. W. Trucks, H. B. Schlegel et al., Eds., ScienceOpen, Berlin, Germany, 2009.

[32] A. Frisch, I. Dennington, T. Keith et al., GaussView Reference, Version 4.0, Gaussian Inc, Wallingford, CT, USA, 2007.

[33] E. Gross and W. Kohn, "Time-dependent density-functional theory," Advances in Quantum Chemistry, vol. 21, pp. 287323, 1990.

[34] N. Hamdi, M. Saoud, A. Romerosa, and R. B. Hassen, "Synthesis, spectroscopic and antibacterial investigations of new hydroxy ethers and heterocyclic coumarin derivatives," Journal of Heterocyclic Chemistry, vol. 57, pp. 1835-1842, 2009.

[35] K. C. Fylaktakidou, D. J. Hadjipavlou-Litina, K. E Litinas, and D. N Nicolaides, "Natural and synthetic coumarin derivatives with antiinflammatory/antioxidant activities," Current Pharmacogenomics, vol. 10, pp. 3813-3833, 2004.

[36] I. Slimani, S. Hamzaoui, L. Mansour, A. Halim Harrath, and N. Hamdi, "One-pot, simple and efficient synthesis of novel bioactive4-aryl-1,2-dihydro-6-(4-hydroxy-2-oxo-2H-chromen-3-yl)-2-oxopyridin-3-carbonitriles via multi-component approach," Journal of King Saud University Science, vol. 32, pp. 1212-1217, 2020.

[37] C. Li, M. R. Lewis, A. B. Gilbert et al., "Antimicrobial activities of amine- and guanidine-functionalized cholic acid derivatives," Antimicrobial Agents and Chemotherapy, vol. 43, no. 6, pp. 1347-1349, 1999.

[38] B. S. Wang, H. Wang, Z. H. Wei, Y. Y. Song, L. Zhang, and H. Z. Chen, "Efficacy and safety of natural acetylcholinesterase inhibitor huperzine A in the treatment of Alzheimer's disease: an updated meta-analysis," Journal of Neural Transmission, vol. 116, pp. 457-465, 2009.

[39] Y. F. Shi, H. Y. Zhang, W. Wang et al., "Novel 16-substituted bifunctional derivatives of huperzine B: multifunctional cholinesterase inhibitors," Acta Pharmacologica Sinica, vol. 30, pp. 1195-1203, 2009.

[40] C. Seidl, B. L. Correia, A. E. M. Stinghen, and C. A. M. Santos, "Acetylcholinesterase inhibitory activity of uleine from Himatanthus lancifolius," Z. Naturforsch.vol. 65, pp. 440-444, 2010.

[41] A. A. N. de Paula, J. B. L. Martins, M. L. dos Santos et al., "New potential AChE inhibitor candidates," European Journal of Medicinal Chemistry, vol. 44, pp. 3754-3759, 2009.

[42] T. D. Z. Atvars, C. A. Bortolato, and D. Dibbern-Brunelli, "Electronic absorption and fluorescence spectra of xanthene dyes in polymers," Journal of Photochemistry and Photobiology A, vol. 68, pp. 41-50, 1992.

[43] J. S. Murray and P. Politzer, "Correlations between the solvent hydrogen-bond-donating parameter alpha. and the calculated molecular surface electrostatic potential," Journal of Organic Chemistry, vol. 56, pp. 6715-6717, 1991.

[44] J. R. Lakowicz and G. Weber, "Quenching of fluorescence by oxygen. A probe for structural fluctuations in macromolecules," Biochemistry, vol. 12, pp. 4161-4170, 1973.

[45] H. Suzuki, "Studies of the effect of ethanol and sodium chloride on the micellization of sodium dodecyl sulphate by gel filtration," Bulletin of the Chemical Society of Japan, vol. 49, pp. 1470-1474, 1976.

[46] R. W. Roberts and D. M. Crothers, "Stability, and properties of double and triple helices: dramatic effects of RNA or DNA backbone composition," Science, vol. 258, pp. 1463-1466, 1992. 